Groundwater Resources Program

\title{
WTAQ Version 2-A Computer Program for Analysis of Aquifer Tests in Confined and Water-Table Aquifers with Alternative Representations of Drainage from the Unsaturated Zone
}

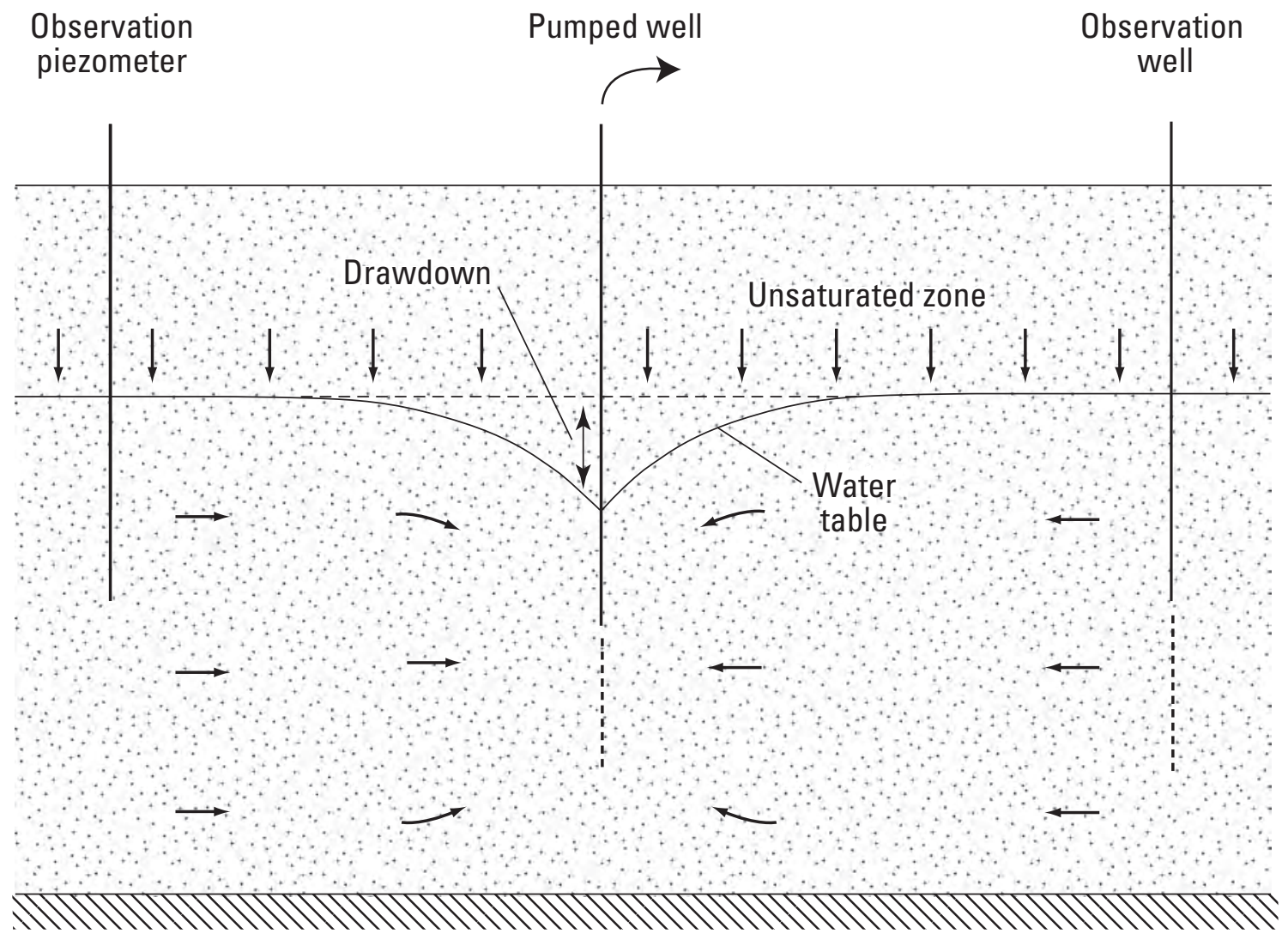

Techniques and Methods 3-B9 
Cover. Schematic diagram of two-dimensional, axial-symmetric flow in a water-table aquifer with one-dimensional, vertical flow in the unsaturated zone. 


\section{WTAQ Version 2-A Computer Program for Analysis of Aquifer Tests in Confined and Water-Table Aquifers with Alternative Representations of Drainage from the Unsaturated Zone}

By Paul M. Barlow and Allen F. Moench

Groundwater Resources Program

Techniques and Methods 3-B9 


\section{U.S. Department of the Interior \\ KEN SALAZAR, Secretary \\ U.S. Geological Survey \\ Marcia K. McNutt, Director}

U.S. Geological Survey, Reston, Virginia: 2011

For more information on the USGS - the Federal source for science about the Earth, its natural and living resources, natural hazards, and the environment, visit http://www.usgs.gov or call 1-888-ASK-USGS.

For an overview of USGS information products, including maps, imagery, and publications, visit http://www.usgs.gov/pubprod

To order this and other USGS information products, visit http://store.usgs.gov

Any use of trade, product, or firm names is for descriptive purposes only and does not imply endorsement by the U.S. Government.

Although this report is in the public domain, permission must be secured from the individual copyright owners to reproduce any copyrighted materials contained within this report.

Suggested citation:

Barlow, P.M., and Moench, A.F., 2011, WTA0 version 2-A computer program for analysis of aquifer tests in confined and water-table aquifers with alternative representations of drainage from the unsaturated zone: U.S. Geological Survey Techniques and Methods 3-B9, 41 p. 


\section{Preface}

This report describes an updated version of the WTAO computer program first published in 1999. The program simulates axial-symmetric flow to a well pumping from a confined or unconfined (water-table) aquifer. The performance of the program has been tested in a variety of applications, some of which are documented in this report. Future applications, however, might reveal errors that were not detected in the test simulations. Users are requested to notify the U.S. Geological Survey of any errors found in this report or the computer program by using the address on the inside of the back cover of the report. Updates might occasionally be made to both the report and to the computer program. Users can check for updates on the Internet at http://water.usgs.gov/software/lists/groundwater/. 


\section{Contents}

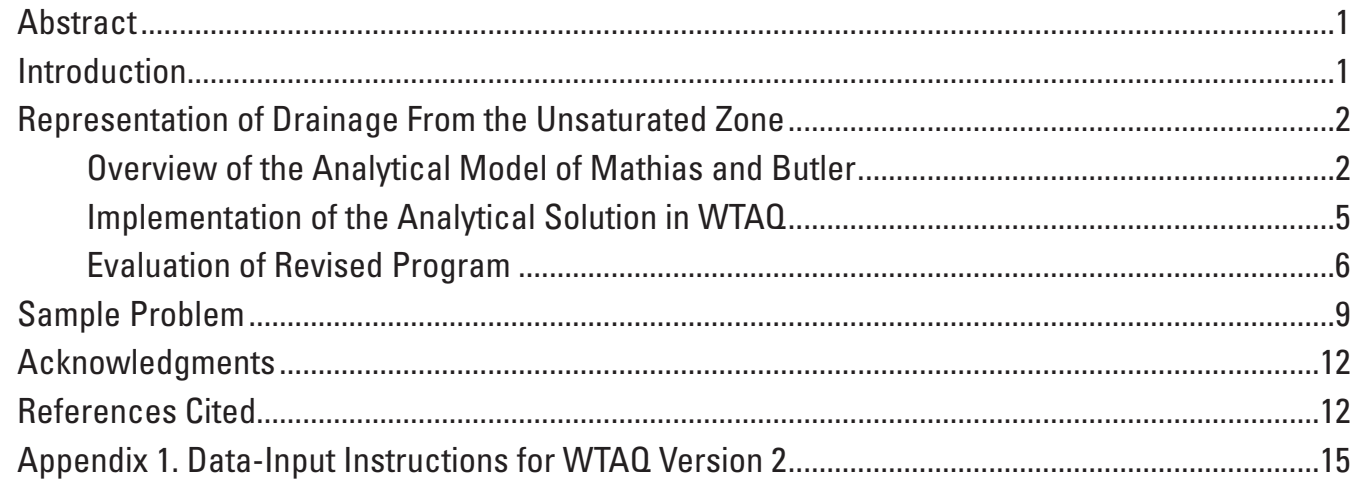

\section{Figures}

1. Diagram showing two-dimensional, axial-symmetric flow in a water-table aquifer with one-dimensional, vertical flow in the unsaturated zone

2. Diagram showing finite-diameter, partially penetrating pumped well in a water-table aquifer.

3. Graph showing dimensionless drawdown as a function of dimensionless time for several values of the dimensionless soil-moisture retention exponent.

4. Graph showing dimensionless drawdown as a function of dimensionless time for several values of the dimensionless relative hydraulic-conductivity exponent.

5. Graph showing dimensionless drawdown as a function of dimensionless time for several values of dimensionless thickness of the unsaturated zone 
6. Diagram showing vertical section of the aquifer at the field site showing the positions of the screened interval of the pumped well, observation piezometers, and neutron-access tube MBN-5

7. (A) Schematic diagram of the soil-moisture content profile at the field site prior to pumping and (B) graph showing background volumetric soil-moisture content above initial water table for neutron-access tube MBN-5 compared with an approximate fit to equation 1 with soil-moisture retention exponent equal to $5 \mathrm{~m}^{-1}$

8. Graphs showing measured and simulated drawdown at several observation piezometers at the field site: (A) piezometers P14 and WD1A; (B) WD2A and WD4A; and (C) P17, P4, and P5 .11

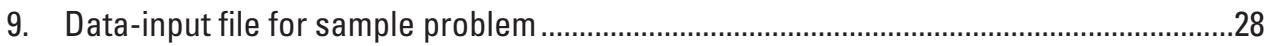

10. Output-results file for sample problem ......................................................................3

\section{Table}

1. Location, depth, and radius of each observation piezometer for sample problem ...........9

\section{Conversion Factors}

\begin{tabular}{lcl}
\hline \multicolumn{1}{c}{ Multiply } & By & \multicolumn{1}{c}{ To obtain } \\
\hline meter $(\mathrm{m})$ & 3.281 & foot $(\mathrm{ft})$ \\
cubic meter per minute $\left(\mathrm{m}^{3} / \mathrm{min}\right)$ & 35.31 & cubic foot per minute $\left(\mathrm{ft}^{3} / \mathrm{min}\right)$ \\
liter per minute $(\mathrm{L} / \mathrm{min})$ & 0.2642 & gallon per minute $(\mathrm{gal} / \mathrm{min})$ \\
meter per minute $(\mathrm{m} / \mathrm{min})$ & 3.281 & foot per minute $(\mathrm{ft} / \mathrm{min})$ \\
\hline
\end{tabular}





\title{
WTAQ Version 2-A Computer Program for Analysis of Aquifer Tests in Confined and Water-Table Aquifers with Alternative Representations of Drainage from the Unsaturated Zone
}

\author{
By Paul M. Barlow and Allen F. Moench
}

\begin{abstract}
The computer program WTAQ simulates axial-symmetric flow to a well pumping from a confined or unconfined (water-table) aquifer. WTAQ calculates dimensionless or dimensional drawdowns that can be used with measured drawdown data from aquifer tests to estimate aquifer hydraulic properties. Version 2 of the program, which is described in this report, provides an alternative analytical representation of drainage to water-table aquifers from the unsaturated zone than that which was available in the initial versions of the code. The revised drainage model explicitly accounts for hydraulic characteristics of the unsaturated zone, specifically, the moisture retention and relative hydraulic conductivity of the soil. The revised program also retains the original conceptualizations of drainage from the unsaturated zone that were available with version 1 of the program to provide alternative approaches to simulate the drainage process. Version 2 of the program includes all other simulation capabilities of the first versions, including partial penetration of the pumped well and of observation wells and piezometers, well-bore storage and skin effects at the pumped well, and delayed drawdown response of observation wells and piezometers.
\end{abstract}

\section{Introduction}

Aquifer-test analyses are one of the most widely used methods for estimating hydraulic properties such as transmissivity, vertical and horizontal hydraulic conductivity, storativity, and specific yield. Several computer programs are available to assist with aquifer-test analysis for a wide range of aquifer conditions and well-design factors. WTAQ is a publicly available program developed by the U.S. Geological Survey for analysis of aquifer tests completed in confined and unconfined (water-table) aquifers (Barlow and Moench, 1999). WTAQ is based on an analytical model developed by Moench (1997; later extended by Moench and others, 2001) for axial-symmetric flow to a partially penetrating, finite-diameter well that pumps water from a homogeneous, anisotropic aquifer. The model accounts for well-bore storage and skin at the pumped well and delayed drawdown response at an observation well or piezometer. WTAQ calculates dimensionless or dimensional drawdowns that can be used with measured drawdowns at observation points to estimate aquifer hydraulic properties. Since its initial release in 1999, WTAQ has been used for the determination of aquifer properties (Kollet and Zlotnik, 2005; Barrash and others, 2006; Endres and others, 2007) and for benchmark testing of numerical models of groundwater flow (Clemo, 2005; Langevin, 2008). As part of a recent textbook on aquifer-test modeling, Walton (2007) provides examples of the use of WTAQ for analysis of aquifer tests in confined and unconfined aquifers.

The analytical model developed by Moench combines and extends the work of Boulton $(1954,1963)$ and of Neuman $(1972,1974)$ to account for the release of water from the unsaturated zone above the water table. In Boulton's approach, drainage from the unsaturated zone is assumed to occur gradually in a manner that varies exponentially with time in response to a unit decline in the elevation of the water table. In Neuman's approach, water is assumed to be released instantaneously (and completely) from the zone above the water table in response to a lowering of the water table. Whereas Boulton's approach is based on a single parameter in the exponential drainage function, Moench's approach allows the user to specify multiple parameters to model the drainage process. Moench has referred to these constants as empirical fitting parameters. Properly evaluated, two or three empirical fitting parameters result in improved matches between simulated and measured drawdowns. 
Several studies over the past 25 years have demonstrated the importance of flow processes in the unsaturated zone to the interpretation of aquifer tests completed in water-table aquifers. These include field investigations reported by Nwankwor and others $(1984,1992)$ and Bevan and others (2005) and analytical- and numerical-modeling investigations described by Akindunni and Gillham (1992), Narasimhan and Zhu (1993), Moench (1995, 2003, 2004), Halford (1997), Moench and others (2001), and Endres and others (2007). The results of these studies point to limitations in the way the Boulton and Neuman models account for drainage from the unsaturated zone.

In an important breakthrough, Mathias and Butler (2006) developed a solution for flow to a well in a water-table aquifer that incorporates explicit representations of unsaturated-zone hydraulic characteristics, specifically, the moisture retention and relative hydraulic conductivity of the soil. The solution was designed to be incorporated into existing analytical solutions such as those developed by Moench. As such, it was used by Moench (2008) in an analysis of a 7-day aquifer test conducted at the Borden research site in Ontario, Canada, wherein measured data included not only drawdown in piezometers but also volumetric soil moisture at various times and distances from the pumped well (Bevan and others, 2005). Moench (2008) demonstrated that the Mathias and Butler model yielded a set of aquifer hydraulic parameters that was consistent with that determined by use of his modified Boulton model with multiple fitting parameters (Moench, 2004) and with results obtained with a numerical model of variably saturated flow (VS2DT; Lappala and others, 1987, Healy, 1990). Separately, Mathias and Butler (2006, figs. 7 and 8 ) demonstrated by analysis of two unconfined aquifer tests that their model was better able to simulate drawdowns at the Borden site than the Moench (1995) model and was able to simulate drawdown at the Cape Cod site about as well as the model of Moench (2004), particularly during the intermediate time period when drainage from the unsaturated zone is important.

Mishra and Neuman (2010) have developed a solution that improves upon a model by Tartakovsky and Neuman (2007) by characterizing relative hydraulic conductivity and water content by two separate exponents and allowing for finite thickness of the unsaturated zone, as accomplished by Mathias and Butler (2006). Unlike the Mathias and Butler (2006) solution, the Mishra and Neuman model accounts for horizontal flow in the unsaturated zone. However, it has the disadvantage that it does not account for storage and skin at the pumped well or delayed piezometer response. Because of this, the model does not properly simulate early-time data and cannot be used to correctly estimate specific storage.

This report documents an update to the WTAQ computer program to include the solution of Mathias and Butler (2006). The updated code is called WTAQ version 2. The report includes a description of the analytical model of Mathias and Butler and its implementation in WTAQ, updated instructions for preparing input files for WTAQ, and a sample problem that demonstrates use of the code. Users of the updated program must refer to the initial WTAQ documentation (Barlow and Moench, 1999) for detailed information on the input parameters and use of the program. All of the capabilities that were available in version 1 of the program are also available in version 2, although the format of the data-input files for the program has changed. Unless otherwise noted, all subsequent references to WTAQ are to version 2 of the program.

\section{Representation of Drainage From the Unsaturated Zone}

This section provides an overview of the analytical model of Mathias and Butler (2006), steps taken to integrate the model into WTAQ, and an evaluation of the solution for hypothetical aquifer conditions to demonstrate behavior of the solution. A full description of the derivation and solution of the model by Mathias and Butler, which is beyond the scope of this report, is provided in their paper. A schematic figure illustrating the underlying conditions for the analytical model is provided in figure 1 .

\section{Overview of the Analytical Model of Mathias and Butler}

The analytical model of Mathias and Butler (2006) extends the work of Boulton (1954, 1963), Dagan (1967), Neuman (1972, 1974), Kroszynski and Dagan (1975), Moench (1995, 1997), and Moench and others (2001) for axial-symmetric flow to a well that pumps from a water-table aquifer. As with the earlier solutions, that of Mathias and Butler is based on a number of simplifying assumptions for the aquifer:

1. The aquifer is homogeneous, of infinite lateral extent, horizontal, and of uniform thickness.

2. The aquifer can be anisotropic provided that the principal directions of the hydraulic-conductivity tensor are parallel to the radial $(r)$ and vertical $(z)$ coordinate axes.

3. Vertical flow across the lower boundary of the aquifer is negligible (that is, the lower boundary is impermeable).

4. A well discharges at a constant rate from a specified zone below an initially horizontal water table. 


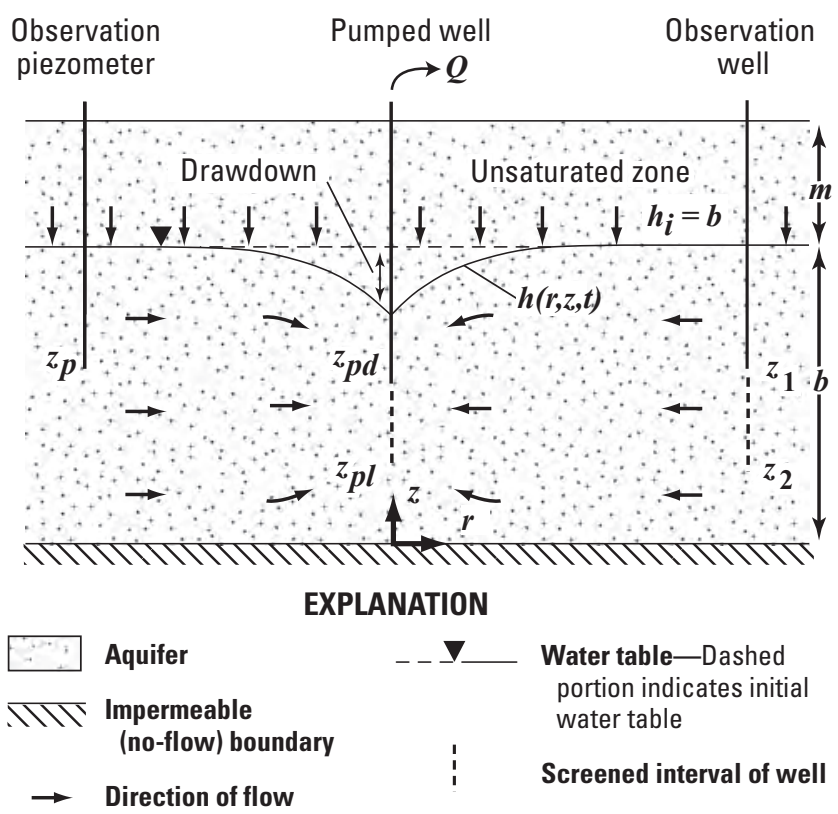

Figure 1. Two-dimensional, axial-symmetric flow in a water-table aquifer with one-dimensional, vertical flow in the unsaturated zone. ( $b$, initial saturated thickness of aquifer; $m$, initial thickness of unsaturated zone; $h(r, z, t)$, head in aquifer at radial distance $r$ from axis of pumped well and height $z$ above the base of the aquifer at time $t ; h_{i}$, initial head in aquifer; $Q$, pumping rate of well; $z_{p d^{\prime}} z_{p l^{\prime}}$ depth below initial water table to the top and bottom, respectively, of the screened interval of the pumped well; $z_{1}, z_{2}$, depth below initial water table to the top and bottom, respectively, of the screened interval of the observation well; $z_{p}$, depth below initial water table to center of piezometer)

5. The porous medium and fluid are slightly compressible and have constant physical properties.

6. The pumped well and observation wells or piezometers are infinitesimal in diameter.

7. The pumped well fully penetrates the aquifer.

8. The change in saturated thickness of the aquifer due to pumping is small compared with the initial saturated thickness.

The several analytical models differ in their treatment of drainage to the pumped aquifer from the overlying unsaturated zone. As described previously, the models of Boulton assume a gradual release of water from the unsaturated zone, whereas those of Neuman assume an instantaneous and complete release of water in response to a lowering of the water table.

Although these models account for the effects of gravity drainage from the unsaturated zone on the response of water levels in the saturated zone, none of them, with the exception of Kroszynski and Dagan (1975), explicitly represent flow within the unsaturated zone or include unsaturated-zone hydraulic characteristics.

The Mathias and Butler model combines the two-dimensional, partial-differential equation of flow within an unconfined aquifer with the one-dimensional form of Richards (1931) equation for vertical flow in a homogeneous unsaturated zone. An important difference between modeling flow in the unsaturated zone and modeling flow in the saturated zone is that it is necessary to specify how soil-moisture content and relative hydraulic conductivity of the unsaturated zone vary as a function of pressure head. Expanding upon the work of Kroszynski and Dagan (1975), Mathias and Butler assumed that both the soilmoisture content and relative hydraulic conductivity can be described by exponential functions of pressure head. Following the approach of Gardner (1958), these functions are written

$$
\begin{gathered}
S_{e}(\psi)=e^{a_{c}\left(\psi-\psi_{S}\right)} \\
\text { and } \\
k_{r e l}(\psi)=e^{a_{k}\left(\psi-\psi_{S}\right)},
\end{gathered}
$$

where

$$
\begin{aligned}
& S_{e}(\psi) \text { and } k_{r e l}(\psi) \text { are the effective-saturation and relative hydraulic-conductivity functions (dimensionless), } \\
& \text { respectively; } \\
& \psi \quad \text { is pressure head in the unsaturated zone (units of length; } \psi<0 \text { ); } \\
& \psi_{S} \quad \text { is pressure head at which the aquifer starts to desaturate (that is, the air-entry pressure head) } \\
& \text { (units of length; } \psi_{S}<0 \text { ); } \\
& a_{c} \quad \text { is the soil-moisture retention exponent (units of inverse length); and } \\
& a_{k} \quad \text { is the relative hydraulic-conductivity exponent (units of inverse length). }
\end{aligned}
$$


Relative hydraulic conductivity $\left(a_{k} k_{r e l}(\psi)\right)$ is defined as the ratio of unsaturated hydraulic conductivity (which is a function of pressure head) to saturated hydraulic conductivity. Effective saturation $\left(S_{e}(\psi)\right)$ is defined as

$$
\frac{\theta-\theta_{r}}{\varphi-\theta_{r}}
$$

where

$$
\begin{array}{ll}
\theta & \text { is the volumetric soil-moisture content, } \\
\theta_{r} & \text { is the residual soil-moisture content, and } \\
\varphi & \text { is the soil porosity. }
\end{array}
$$

The sample problem described later in this report illustrates how $a_{c}$ and $\psi_{S}$ can be estimated from measurements of volumetric soil-moisture content.

The relative hydraulic-conductivity and effective-saturation functions are related by (Mathias and Butler, 2006, eq. 6)

$$
k_{r e l}\left(S_{e}\right)=S_{e}^{a_{k} / a_{c}}
$$

By analogy to the models of relative permeability developed by Burdine (1953) and Mualem (1976), the exponent $a_{k} / a_{c}$ should be greater than or equal to 1.0 and as a result, $a_{k} \geq a_{c}$, which is a necessary condition for the analytical solution implemented in WTAQ (S.A. Mathias, Durham University, United Kingdom, written commun., 2010).

Mathias and Butler (2006) derive their solution to the coupled-flow model by linearizing the Richards equation. This approach requires an extension of assumption 8 listed above; specifically, that the changes in the initial thickness of the unsaturated zone $(m)$ and the initial saturated thickness of the aquifer $(b)$ due to pumping are small compared to the initial conditions. The solution to the coupled-flow model results in an analytical expression for drainage from the unsaturated zone (equation 42 in Mathias and Butler) that can be incorporated into the Laplace-transform solutions for flow to a well in an unconfined aquifer that are the basis of version 1 of WTAQ (specifically, equation 24 in Moench, 1997; equation 20 in Moench and others, 2001).

The approach taken by Mathias and Butler (2006) is an extension of earlier work by Kroszynski and Dagan (1975) and is similar to the approach taken by Tartakovsky and Neuman (2007). However, unlike the models of Kroszynksi and Dagan (1975) and Tartakovsky and Neuman (2007), the model of Mathias and Butler does not require that the soil-moisture retention and relative hydraulic-conductivity exponents be equal. Moench (2008) has shown that the assumption $a_{c}=a_{k}$ is unrealistic for field applications. The Mathias and Butler model also accounts for elastic storage in the saturated zone and allows for a finite thickness of the unsaturated zone, neither of which was accounted for by Kroszynski and Dagan (1975). Unlike the model of Tartakovsky and Neuman, however, the Mathias and Butler model assumes that horizontal flow in the unsaturated zone can be neglected. 


\section{Implementation of the Analytical Solution in WTAQ}

Because the drainage function derived by Mathias and Butler can be incorporated into the solutions derived by Moench, all of the simulation capabilities that are provided by the first version of WTAQ are included with version 2 of the program. These include partial penetration of the pumped well and of observation wells and piezometers, well-bore storage and skin effects at the pumped well, and delayed drawdown response of observation wells and piezometers (these conditions are shown schematically in figure 2). Barlow and Moench (1999) provide a full description of all these simulation capabilities and a summary of the additional simplifying assumptions necessary for the simulation of these conditions.

WTAQ uses numerical-inversion techniques to invert the Laplace-transform (LT) analytical solutions developed by Moench (2008) and Mathias and Butler (2006) into the real-time domain. All LT solutions provided in version 1 of the program were inverted by use of the Stehfest (1970) algorithm. In version 2, however, either the Stehfest (1970) or de Hoog (de Hoog and others, 1982) algorithms can be employed at the discretion of the user. A new variable (ISOLN) has been added to WTAQ to specify which inversion algorithm is to be used. For simulation of confined aquifers using WTAQ versions 1 or 2 , the Stehfest algorithm must be used. For simulation of water-table aquifers with either the Boulton or Neuman models for drainage from the unsaturated zone, the Stehfest algorithm is recommended, although either the Stehfest or de Hoog algorithms can be used if a comparison of results is desired. For simulation of drainage that is based on the Mathias and Butler model, the de Hoog algorithm must be used because the LT solution of Mathias and Butler is expressed in complex notation. (Use of the Stehfest algorithm requires the LT solution be expressed in real notation.) Both the Stehfest and de Hoog algorithms have occasional stability problems that are likely to occur at early time (that is, large values of the LT variable). If they occur, they may be a consequence of the choice of algorithm options (input variables that must be specified for use of each algorithm are described in the appendix).

WTAQ version 2 consists of four FORTRAN-language computer programs that are linked during program compilation: 1. The main program wtaq.v2.f, which organizes the tasks completed by WTAQ and calls many of the subroutines; 2. Program subs.io.f, which comprises subroutines related to opening the input, output results, and plot files, reading of input data, and writing of a program banner to the results file; 3. Program subs.inverse.f, which comprises subroutines related to the Stehfest and de Hoog numerical-inversion methods for solution of the analytical equations; and 4. Program subs.besselmb.f, which comprises the Bessel functions used in the equations of Mathias and Butler (2006) that were developed by Amos (1986).

Figure 2. Finite-diameter, partially penetrating pumped well in a water-table aquifer. ( $b$, initial saturated thickness of aquifer; $d_{s^{\prime}}$ thickness of the well-bore skin; $h(r, z, t)$, head in aquifer at radial distance $r$ from axis of pumped well and height $z$ above the base of the aquifer at time $t ; h_{i}$, initial head in aquifer; $Q$, pumping rate of well; $r_{c}, r_{p}$, inside radius of the pumped well and observation well, respectively, in the interval where water levels are changing during pumping; $r_{w}$, radius of the screened interval of the pumped well; $z_{p d}, z_{p l}$, depth below initial water table to the top and bottom, respectively, of the screened interval of the pumped well; $z_{1}, z_{2}$, depth below initial water table to the top and bottom, respectively, of the screened interval of the observation well)

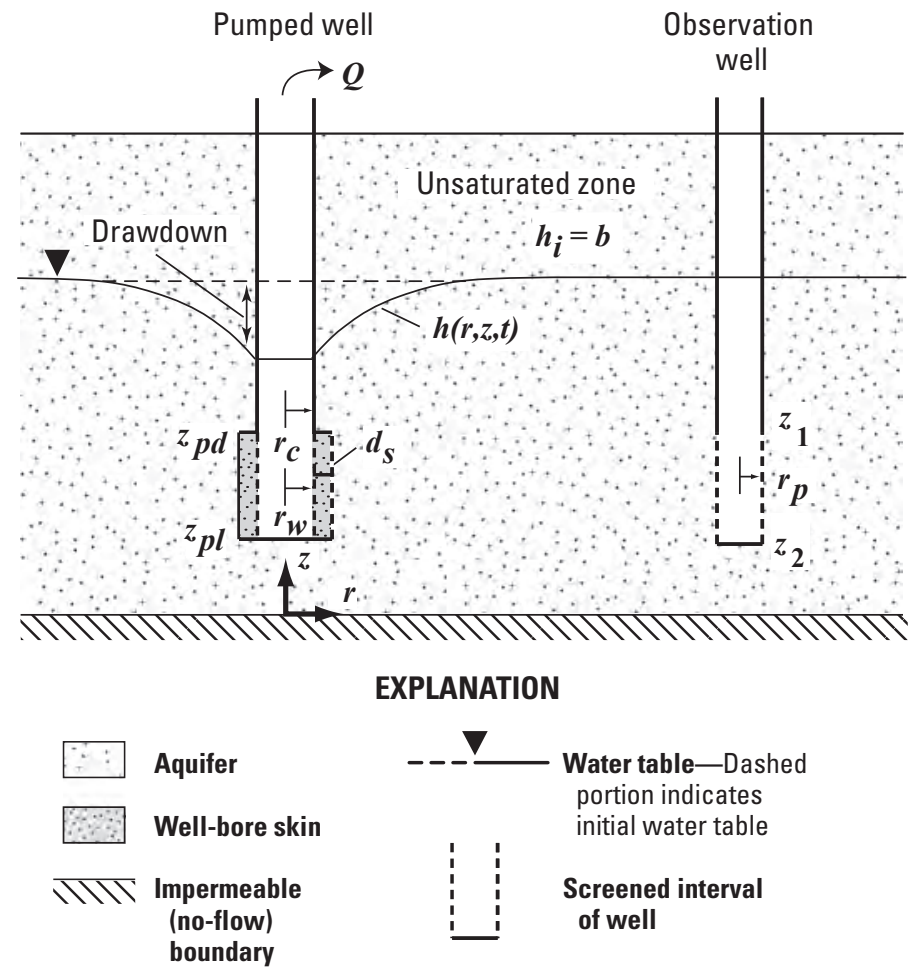




\section{Evaluation of Revised Program}

Several tests were made to confirm that the revised program works correctly. First, three of the sample problems that were described in Barlow and Moench (1999) and are distributed with the program (problems SP1, SP2, and TEST1) were rerun with the revised program. Each of these sample problems simulates water-table aquifers with instantaneous drainage above the declining water table; in each case, the Stehfest algorithm was used to numerically invert the Laplace-transform analytical solutions. Drawdowns calculated with the revised program were identical to those calculated with version 1 of the program for several simulated conditions that included simulation of gradual drainage from the unsaturated zone (that is, variable IDRA set to 1). The input file for each sample problem was then modified such that the de Hoog algorithm was used to calculate drawdowns. Results from these simulations were nearly identical to those calculated with the Stehfest algorithm, indicating that either algorithm adequately simulates drawdown in the water-table aquifers.

Three sets of tests were then carried out to verify that the analytical solution of Mathias and Butler (2006) was correctly implemented in the code. The tests were based on simulated conditions that closely follow the hypothetical aquifer and unsaturated-zone conditions described in Mathias and Butler. The simulated water-table aquifer has an initial saturated thickness of $10 \mathrm{~m}$. The vertical $\left(K_{z}\right)$ and radial $\left(K_{r}\right)$ hydraulic conductivity of the aquifer are assumed to be equal, so that $K_{z} / K_{r}=1$. Values of specific storage $\left(S_{s}\right)$ and specific yield $\left(S_{y}\right)$ of the aquifer were chosen such that the dimensionless variable $\sigma\left(S_{s} b / S_{y}\right)$ has a value of $1.0 \times 10^{-3}$. The pumped well is assumed to fully penetrate the aquifer. Drawdowns were calculated for an observation piezometer that is located $10 \mathrm{~m}$ from the pumped well and is open to the aquifer at the water table.

Results of the test simulations are shown as dimensionless drawdowns calculated for several values of dimensionless time. Dimensionless drawdown and dimensionless time are defined for WTAQ in Barlow and Moench (1999, p. 25). Dimensionless time-drawdown curves also were calculated for assumed Theis-type confined-aquifer conditions for comparison to the watertable aquifer solutions. Two confined-aquifer conditions were simulated, the first for dimensionless time as a function of storativity of the aquifer $(S)$ and the second for dimensionless time as a function of specific yield $\left(S_{y}\right)$. The resulting timedrawdown curves are referred to as "Theis $(S)$ " and "Theis $\left(S_{y}\right)$ " on figures 3-5.

Three sets of tests were run to evaluate the effects of the three parameters that are required for the model of Mathias and Butler (2006): the soil-moisture retention exponent, $a_{c}$; the relative hydraulic-conductivity exponent, $a_{k}$; and the initial thickness of the unsaturated zone at the start of the aquifer test, $m$. In the first two sets of tests, the unsaturated zone is assumed to have an infinite thickness. This assumption is made to simplify the simulation process, which is possible because the solution of Mathias and Butler is easier to evaluate if the unsaturated zone has an infinite thickness (see Mathias and Butler, 2006, equation 46 and preceding discussion). In all cases tested, was specified to be greater than or equal to $a_{c}$.

The first set of tests was done to evaluate the sensitivity of calculated drawdown to the soil-moisture retention exponent $a_{c}$. Values of $a_{c}$ were selected such that values of the dimensionless soil-moisture retention exponent $a_{D c}\left(a_{D c}=a_{c} b\right)$ were equal to $0.1,1.0,10.0$, and 1,000 . In each simulation, the value of the relative hydraulic-conductivity exponent $a_{k}$ was set equal to $a_{c}$. The results of the test simulations are shown in figure 3 and closely follow those shown in figure 2 of Mathias and Butler (2006) for similar simulated conditions. The results for $a_{D c}=1,000$ are shown on the figure as $a_{D c}=\infty$ and indicate that as the value of the soil-moisture retention exponent becomes very large, drainage from the unsaturated zone becomes instantaneous. This conclusion was confirmed by simulating the same aquifer conditions with an assumption of instantaneous drainage from the unsaturated zone (that is, the Neuman approach); results for the simulation overlie those shown on the figure for $a_{D c}=\infty$. As noted by Mathias and Butler, as $a_{D c}$ decreases, the unsaturated zone becomes harder to drain and drawdown in the aquifer is larger at early times than is that calculated for larger values of $a_{D c^{*}}$. As dimensionless time increases, all the drawdown curves approach the "late-time" Theis solution (that is, the Theis $(S y)$ curve), which indicates that as time progresses, the rate of drainage from the unsaturated zone approaches the rate of decline in the water table. 


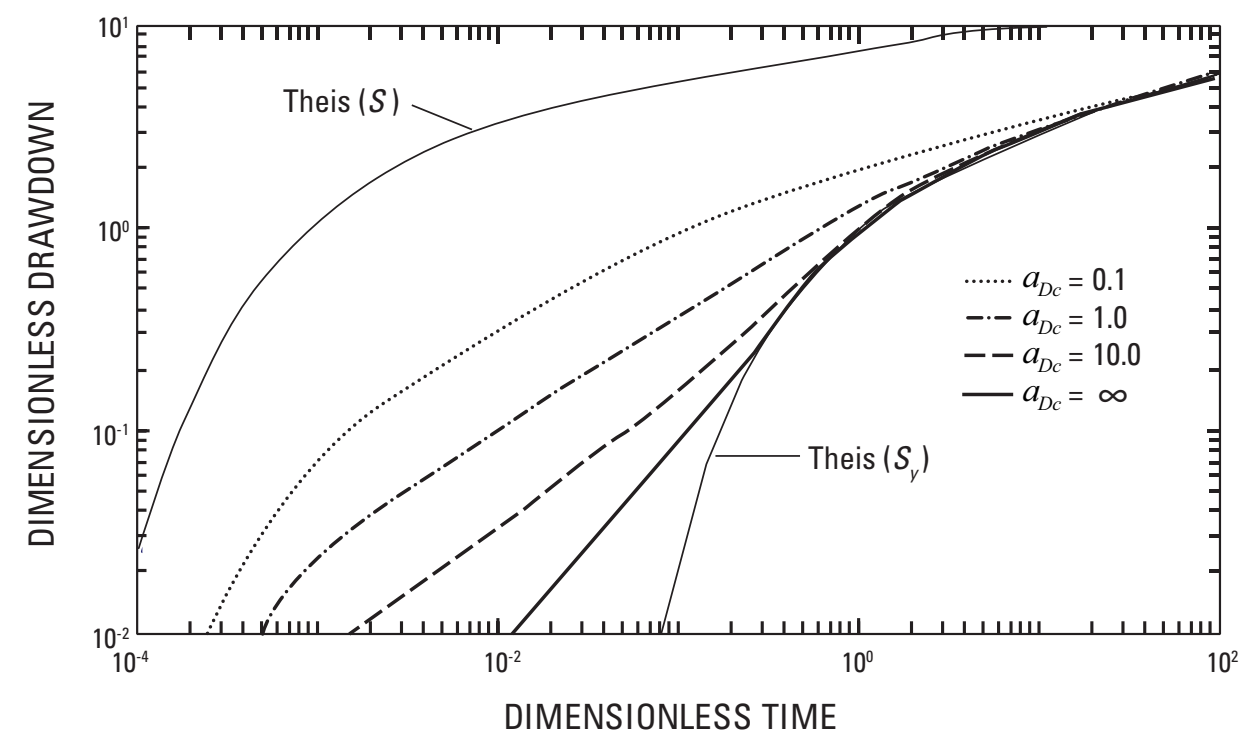

Figure 3. Dimensionless drawdown as a function of dimensionless time for several values of the dimensionless soil-moisture retention exponent $\left(a_{D c}\right)$. For the simulations shown, the values of the soil-moisture retention exponent and relative hydraulic-conductivity exponent were set equal to one another, and the unsaturated zone was assumed to have an infinite thickness. (The two curves labeled Theis $(S)$ and Theis $\left(S_{y}\right)$ are results for confined-aquifer conditions with dimensionless time as a function of storativity and specific yield, respectively.)

The second set of tests evaluated the sensitivity of calculated drawdowns to the relative hydraulic-conductivity exponent $a_{k}$. As with the first set of simulations, the thickness of the unsaturated zone was assumed to be infinite. Values of $a_{k}$ were selected such that the values of the dimensionless relative hydraulic-conductivity exponent $a_{D k}\left(a_{D k}=a_{k} b\right)$ were equal to $1.0,100,1,000$, and 10,000. In each simulation, the value of the soil-moisture retention exponent $a_{c}$ was set equal to $0.1 \mathrm{~m}^{-1}\left(a_{D c}=1.0\right)$. The results of the test simulations are shown in figure 4 and closely follow those shown in figure 4 of Mathias and Butler for similar simulated conditions. (Note: Two of the curves on figure 4 of the Mathias and Butler paper appear to be mislabeled. The curve shown as $a_{D k}=10^{1}$ is apparently $10^{2}$ and that labeled $10^{5}$ is apparently $10^{4}$ ). As the value of $a_{k}$ is increased, there is an exponential decline in the value of the relative hydraulic conductivity (eq. 2), and water drains more slowly from the unsaturated zone; for extremely large values of $a_{k}$, the aquifer behaves like a confined aquifer in which there is no drainage from the unsaturated zone (that is, the curves approach the "Theis (S)" curve).

In the final set of simulations, the unsaturated zone was assumed to have a finite thickness. Values of the initial thickness of the unsaturated zone $(m)$ were varied such that the dimensionless thickness of the unsaturated zone $\left(m_{D}=m / b\right)$ had simulated values of $0.001,0.01,0.1$, and 100 (the value of 100 was assumed to equal infinity, $\infty$ ). In each simulation, the values of $a_{D c}$ and $a_{D k}$ were held constant at 1.0. The results of the simulations are shown in figure 5 and are equivalent to those provided in Mathias and Butler (2006, fig. 3) for the same simulation conditions. The curve for an infinitely thick unsaturated zone $\left(m_{D}=\infty\right)$ is equivalent to that for $a_{D k}=1.0$ in figure 4. As the initial thickness of the unsaturated zone decreases, less water is available for drainage from the unsaturated zone, and drawdowns approach those for a confined aquifer with no drainage of aquifer porosity (that is, drawdowns approach the "Theis (S)" curve). 


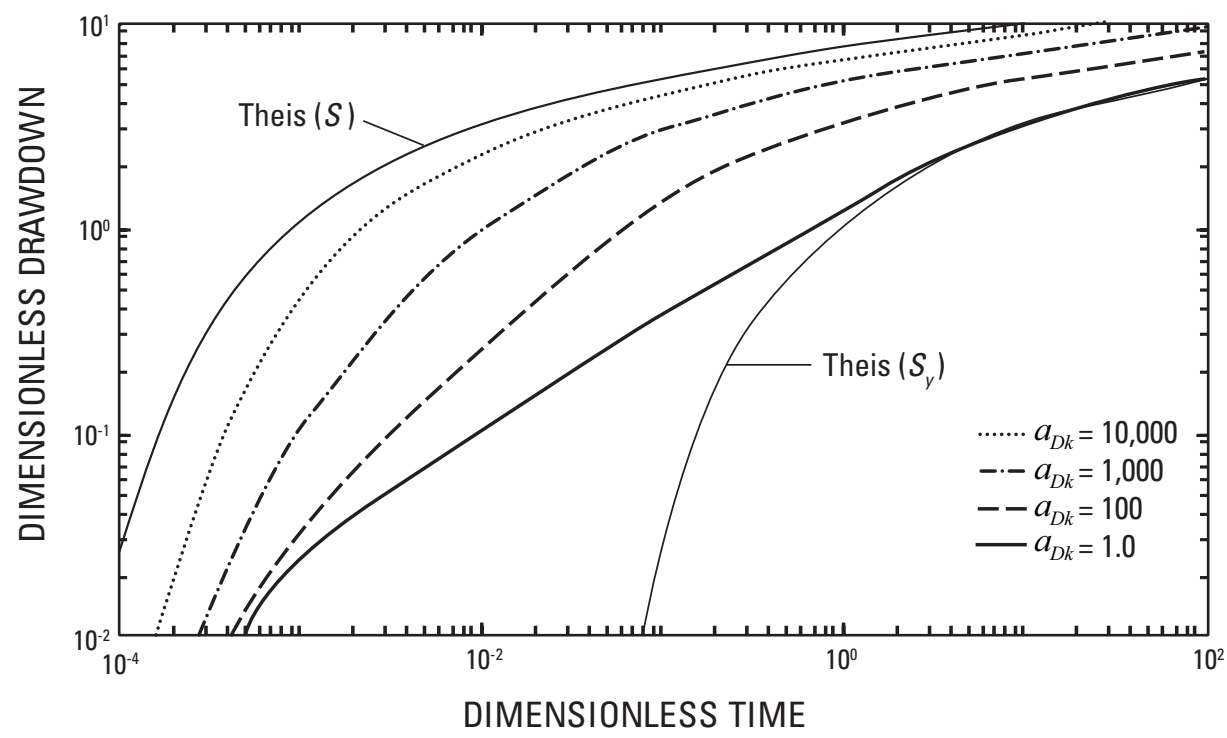

Figure 4. Dimensionless drawdown as a function of dimensionless time for several values of the dimensionless relative hydraulic-conductivity exponent $\left(a_{D k}\right)$. For the simulations shown, the value of the dimensionless soil-moisture retention exponent was set equal to 1.0, and the unsaturated zone was assumed to have an infinite thickness. (The two curves labeled Theis $(S)$ and Theis $\left(S_{y}\right)$ are results for confined-aquifer conditions with dimensionless time as a function of storativity and specific yield, respectively.)

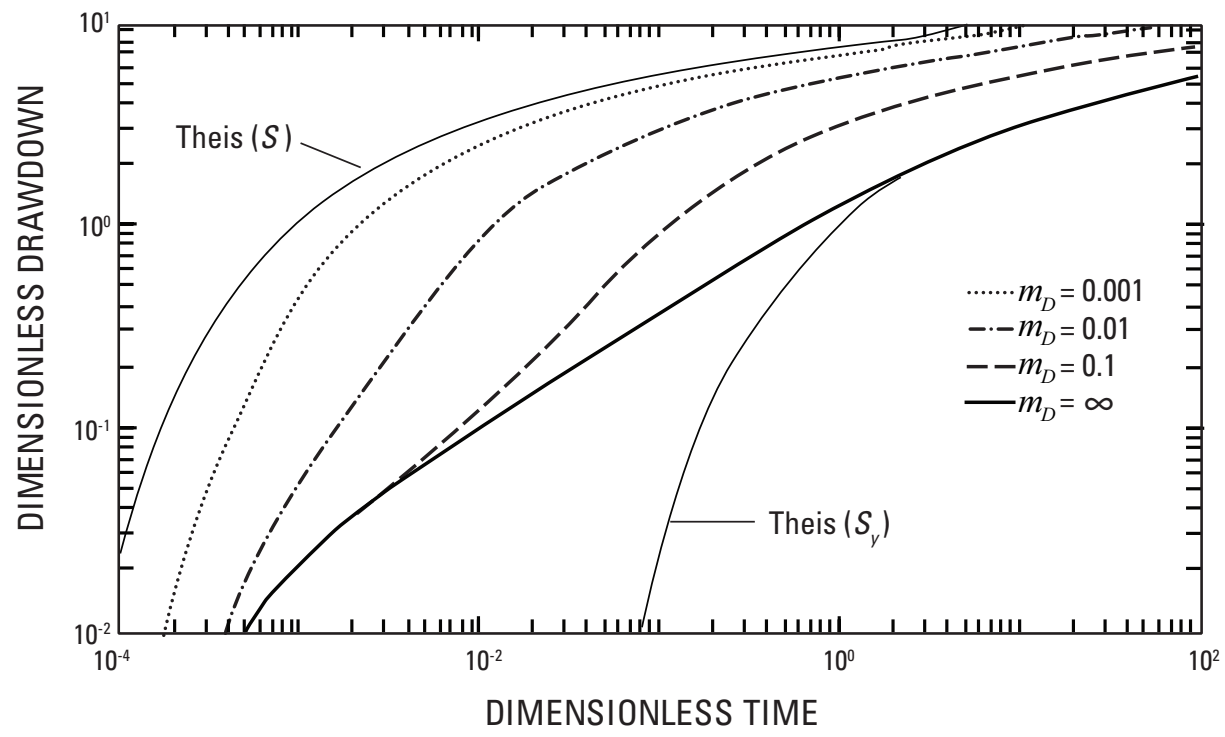

Figure 5. Dimensionless drawdown as a function of dimensionless time for several values of dimensionless thickness of the unsaturated zone $\left(m_{D}\right)$. For the simulations shown, the values of the soil-moisture retention exponent and relative hydraulic-conductivity exponent were set equal to 1.0. (The two curves labeled Theis $(S)$ and Theis $\left(S_{y}\right)$ are results for confined-aquifer conditions with dimensionless time as a function of storativity and specific yield, respectively.) 


\section{Sample Problem}

A sample problem (SP3) is provided to demonstrate use of the new option for drainage from the unsaturated zone that is based on the conceptual model of coupled saturatedunsaturated flow developed by Mathias and Butler (2006). The problem uses data collected during a 7-day aquifer test completed in August 2001 at the well-instrumented field site at Canadian Forces Base Borden, near Barrie, Ontario, described in Bevan and others (2005). Over the past 25 years, the Borden site has been the focus of numerous investigations of saturated and unsaturated flow in response to pumping from an unconfined aquifer (Nwankwor and others, 1984, 1992; Akindunni and Gillham, 1992; Bevan and others, 2005; Endres and others, 2007). Data collection during the test included measuring drawdown at the pumped well and at more than 40 observation piezometers and monitoring of soil-moisture content profiles at six neutron moisture-probe access tubes (Bevan and others, 2005).

The unconfined aquifer at the Borden site is composed primarily of medium-grained sand of glacio-deltaic or glacio-fluvial origin (Bevan and others, 2005). Although the aquifer is locally heterogeneous because of discontinuous beds of fine-, medium-, and coarse-grained sand, overall it

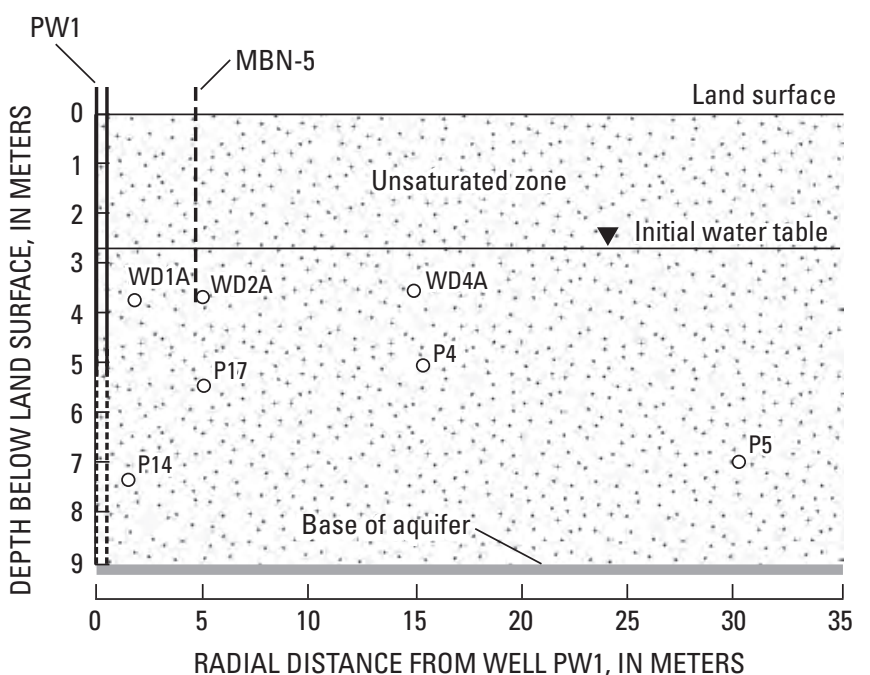

Figure 6. Vertical section of the aquifer at the field site showing the positions of the screened interval of the pumped well (identified as PW1), observation piezometers (shown as open circles, with identifiers), and neutron-access tube MBN-5. (Modified from Moench, 2008.)

has a low degree of spatial variability and is considered to be homogeneous to flow at the scale of the aquifer test. The aquifer overlies a clayey silt confining aquifer that is assumed to be an impermeable barrier to flow at a depth of about $9 \mathrm{~m}$ below land surface. Depth to the water table prior to the test was about $2.75 \mathrm{~m}$ below land surface; therefore, the initial saturated thickness of the aquifer was about $6.25 \mathrm{~m}$ (fig. 6).

The pumped well at the site is screened over the bottom $3.65 \mathrm{~m}$ of the aquifer and has an internal radius of $0.065 \mathrm{~m}$. The well was pumped at a constant discharge rate of $40 \mathrm{~L} / \mathrm{min}(0.04 \mathrm{~m} / \mathrm{min})$ during the 7-day test. Although drawdowns were monitored at all observation piezometers (Bevan and others, 2005), data collected from only seven of the piezometers are used in the sample problem. The radial distance of each piezometer from the pumped well, the center of the screened interval of each piezometer, and the radius of each piezometer are provided in table 1. Delayed drawdown response at all but one of the piezometers (P5) was simulated with WTAQ. In all cases, the length of the screened interval of each piezometer was specified to be $0.35 \mathrm{~m}$, on the basis of information in Bevan and others (2005).

\begin{tabular}{|c|c|c|c|}
\hline \multicolumn{4}{|c|}{ [All units are in meters] } \\
\hline Piezometer & $\begin{array}{l}\text { Radial distance } \\
\text { from center of } \\
\text { pumped well }\end{array}$ & $\begin{array}{l}\text { Depth below } \\
\text { initial water } \\
\text { table to center } \\
\text { of piezometer } \\
\text { well screen }\end{array}$ & $\begin{array}{l}\text { Radius of } \\
\text { piezometer }\end{array}$ \\
\hline WD1A & 1.51 & 0.94 & 0.025 \\
\hline WD2A & 5.07 & 0.89 & 0.025 \\
\hline WD4A & 15.05 & 0.84 & 0.025 \\
\hline P17 & 5.15 & 2.69 & 0.025 \\
\hline P4 & 15.36 & 2.32 & 0.0175 \\
\hline P14 & 1.51 & 4.57 & 0.025 \\
\hline P5 & 30.19 & 4.30 & 0.025 \\
\hline
\end{tabular}


Data from the test have been used by Endres and others (2007) and Moench (2008) to estimate hydraulic properties of the aquifer. With the exception of the estimated value of specific storage, the values of the hydraulic properties estimated by the two researchers are similar but differ partly because Endres and others (2007) did not use the complete data set collected by Bevan (2002). Because the estimates made by Moench are based on the Mathias and Butler model, they are used in this sample problem. The estimates are (Moench, 2008, table 3a): $b, 6.20 \mathrm{~m} ; K_{r}, 4.10 \times 10^{-3} \mathrm{~m} / \mathrm{min} ; K_{z}, 1.74 \times 10^{-3} \mathrm{~m} / \mathrm{min}$; $S_{s}, 3.76 \times 10^{-5} \mathrm{~m}^{-1}$; and $S_{y}, 0.25$ (see discussion following table 3a in Moench, 2008). Moench also estimated a value of the skin parameter for the pumped well $\left(S_{w}\right)$ of 1.74. As part of the analysis, Moench (2008) assumed the unsaturated zone was infinitely thick. This assumption was based on soil-moisture measurements made at the field site that indicated the land surface was well above the transition zone that extends from the top of the capillary fringe at full moisture saturation to the water content at residual saturation (fig. 7A). Moench (2008) estimated a value of $a_{c}$ equal to $5.0 \mathrm{~m}^{-1}$ at the field site by visually fitting equation 1 to measurements of volumetric soil-moisture content above the initial water table made at neutron access tube MBN-5 (with $\psi_{S}$, the air-entry pressure equal, estimated to be $-0.40 \mathrm{~m}$ ). He also estimated $a_{k}$ to be $31.7 \mathrm{~m}^{-1}$ by use of the drawdown data available at the site and nonlinear parameter-estimation techniques.

The de Hoog numerical-inversion algorithm is required for simulating drawdown with the Mathias and Butler (2006) solution. The following program solution variables for the de Hoog algorithm, which are described in the appendix, were found to give adequate results: $\mathrm{RERRNR}=1.0 \times 10^{-10}, \mathrm{ERROR}=1.0 \times 10^{-4}, \mathrm{NTMS}=30, \mathrm{NNN}=6$, and $\mathrm{METHOD}=3$.

A data-input file for WTAQ version 2 was prepared on the basis of information given in the preceding discussion. Drawdown data measured at the piezometers are available in Michael Bevan's thesis (Bevan, 2002) but are not listed here for proprietary reasons; if needed, the data can be requested from the University of Waterloo. Drawdowns calculated by WTAQ at the observation piezometers are plotted in figure 8 and, as would be expected, are consistent with the results shown in Moench (2008). The data-input and model-output files for this sample problem are shown in figures 9 and 10 (at back of report).
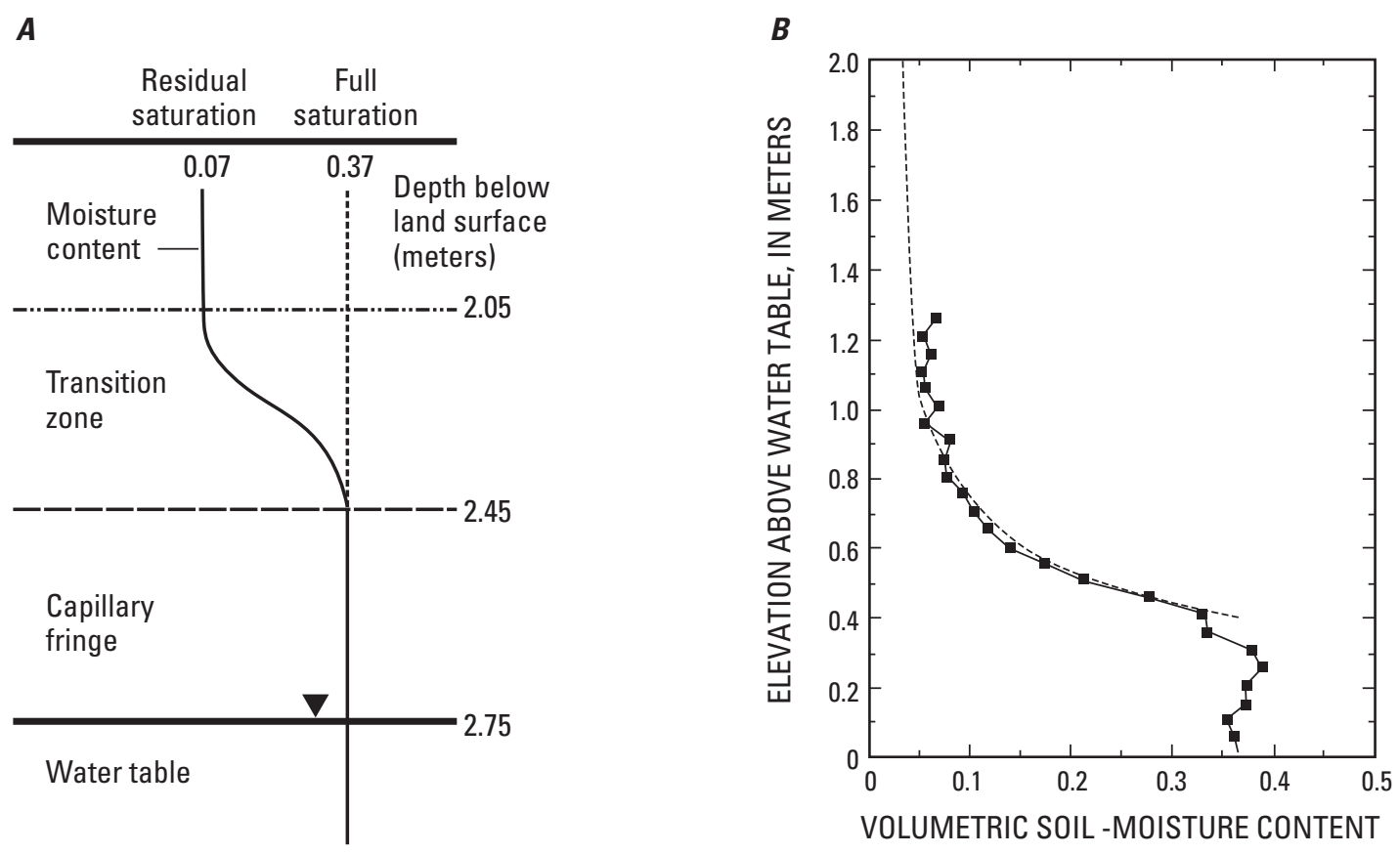

Figure 7. (A) Schematic diagram of the soil-moisture content profile at the field site prior to pumping (modified from Bevan and others, 2005) and (B) graph showing background volumetric soil-moisture content above initial water table for neutron-access tube MBN-5 (black squares) compared with an approximate fit to equation 1 with soil-moisture retention exponent $\left(a_{c}\right)$ equal to $5 \mathrm{~m}^{-1}$ (dashed line) (modified from Moench, 2008). 

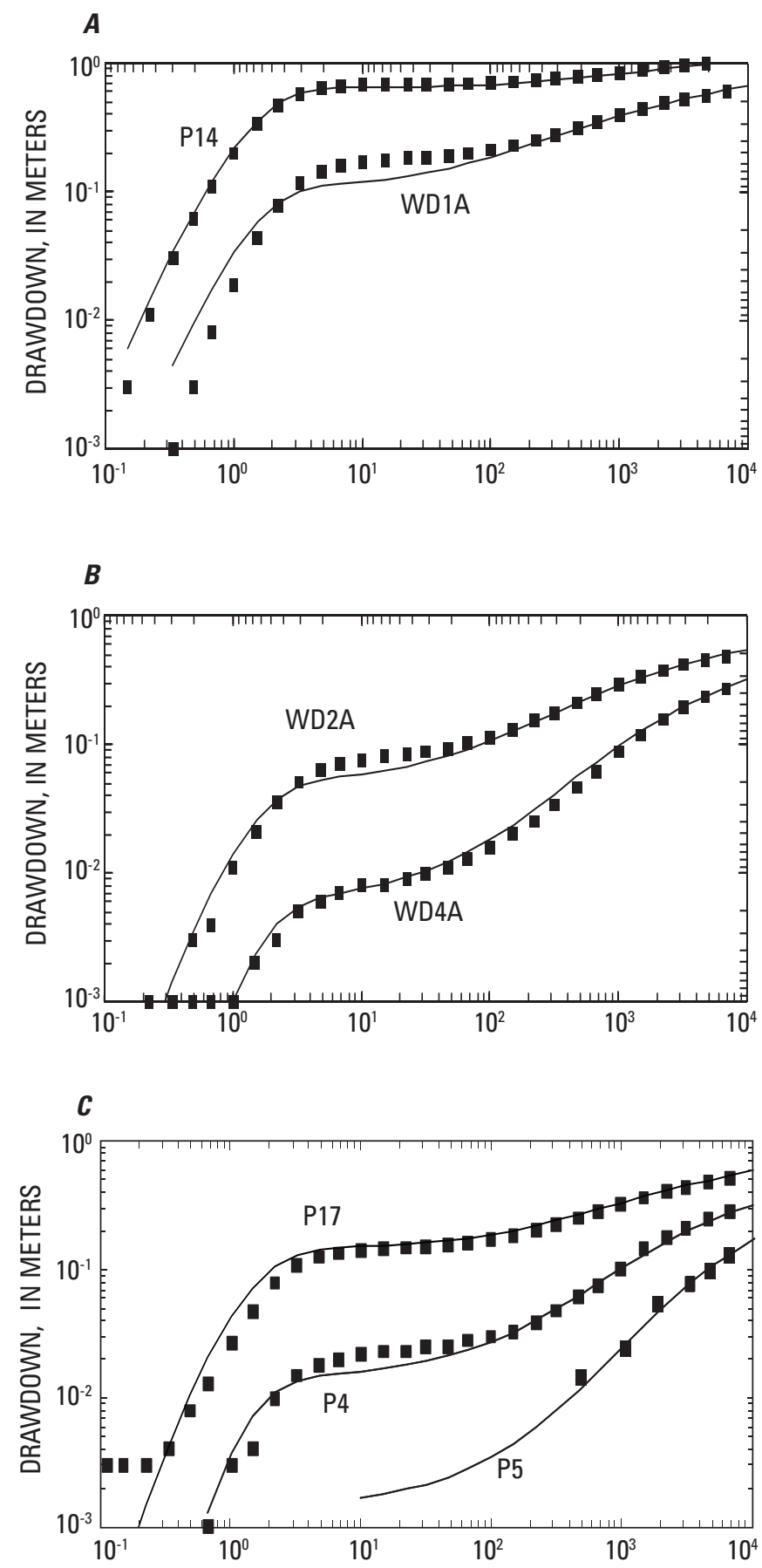

TIME, IN MINUTES

Figure 8. Measured and simulated drawdown at several observation piezometers at the field site: $(A)$ piezometers $\mathrm{P} 14$ and WD1A; (B)WD2A and WD4A; and (C) P17, P4, and P5. Measured data are shown by squares; simulated results are shown by lines. 


\section{Acknowledgments}

The authors thank John Knight (School of Mathematical Sciences, Queensland University of Technology, Brisbane, Australia) for the use of his FORTRAN subroutine that implements the de Hoog algorithm (de Hoog and others, 1982). The authors also thank Keith Halford, Christian Langevin, and Kim Otto of the U.S. Geological Survey for their helpful review comments on a draft of this report.

\section{References Cited}

Akindunni, F.F., and Gillham, R.W., 1992, Unsaturated and saturated flow in response to pumping of an unconfined aquiferNumerical investigation of delayed drainage: Ground Water, v. 30, no. 6, p. 873-884.

Amos, D.E., 1986, A portable package for Bessel functions of a complex argument and nonnegative order: ACM Transactions on Mathematical Software, v. 12, no. 3, p. 265-273.

Barlow, P.M., and Moench, A.F., 1999, WTAQ-A computer program for calculating drawdowns and estimating hydraulic properties for confined and water-table aquifers: U.S. Geological Survey Water-Resources Investigations Report 99-4225, $74 \mathrm{p}$.

Barrash, Warren, Clemo, Tom, Fox, J.J., and Johnson, T.C., 2006, Field, laboratory, and modeling investigation of the skin effect at wells with slotted casing, Boise Hydrogeophysical Research Site: Journal of Hydrology, v. 326, p. 181-198.

Bevan, M.J., 2002, A detailed study of water content variation during pumping and recovery in an unconfined aquifer: Waterloo, Ontario, University of Waterloo, M.Sci. thesis, 120 p.

Bevan, M.J., Endres, A.L., Rudolph, D.L., and Parkin, Gary, 2005, A field scale study of pumping-induced drainage and recovery in an unconfined aquifer: Journal of Hydrology, v. 315, p. 52-70.

Boulton, N.S., 1954, Unsteady radial flow to a pumped well allowing for delayed yield from storage: Rome, International Association of Scientific Hydrology, Publication 37, p. 472-477.

Boulton, N.S., 1963, Analysis of data from non-equilibrium pumping tests allowing for delayed yield from storage: Proceedings-Institution of Civil Engineers, v. 26, p. 469-482.

Burdine, N.T., 1953, Relative permeability calculations from pore size distribution data: Transactions of the American Institute of Mining, Metallurgical and Petroleum Engineers, v. 198, p. 71-78.

Clemo, Tom, 2005, Improved water table dynamics in MODFLOW: Ground Water, v. 43, no. 2, p. 270-273.

Dagan, G., 1967, A method of determining the permeability and effective porosity of unconfined anisotropic aquifers: Water Resources Research, v. 3, no. 4, p. 1059-1071.

de Hoog, F.R., Knight, J.H., and Stokes, A.N., 1982, An improved method for numerical inversion of Laplace transforms: SIAM Journal of Scientific Computing, v. 3, p. 357-366.

Endres, A.L., Jones, J.P., and Bertrand, E.A., 2007, Pumping-induced vadose zone drainage and storage in an unconfined aquifer-A comparison of analytical model predictions and field measurements: Journal of Hydrology, v. 335, p. $207-218$.

Gardner, W.R., 1958, Some steady state solutions of the unsaturated moisture flow equations with application to evaporation from a water table: Soil Science, v. 85, p. 228-232.

Halford, K.J., 1997, Effects of unsaturated zone on aquifer test analysis in a shallow-aquifer system: Ground Water, v. 35, no. 3, p. 512-522.

Healy, R.W., 1990, Simulation of solute transport in variably saturated porous media with supplemental information on modifications to the U.S. Geological Survey's computer program VS2D: U.S. Geological Survey Water-Resources Investigations Report 90-4025, 125 p. 
Kollet, S.J., and Zlotnik, V.A., 2005, Influence of aquifer heterogeneity and return flow on pumping test data interpretation: Journal of Hydrology, v. 300, p. 267-285.

Kroszynski, U.I., and Dagan, G., 1975, Well pumping in unconfined aquifers: The influence of the unsaturated zone: Water Resources Research, v. 11, no. 3, p. 479-490.

Langevin, C.D. 2008, Modeling axisymmetric flow and transport: Ground Water, v. 46, no. 4, p. 579-590.

Lappala, E.G., Healy, R.W., and Weeks, E.P., 1987, Documentation of computer program VS2D to solve the equations of fluid flow in variably saturated porous media: U.S. Geological Survey Water-Resources Investigations Report 83-4099, 184 p.

Mathias, S.A., and Butler, A.P., 2006, Linearized Richards' equation approach to pumping test analysis in compressible aquifers: Water Resources Research, v. 42, W06408, doi:10.1029/2005WR004680, 10 p.

Mishra, P.K., and Neuman, S.P., 2010, Improved forward and inverse analyses of saturated-unsaturated flow toward a well in a compressible unconfined aquifer: Water Resources Research, v. 46, W07508, doi:10.1029/2009WR008899.

Moench, A.F., 1995, Combining the Neuman and Boulton models for flow to a well in an unconfined aquifer: Ground Water, v. 33, no. 3, p. 378-384.

Moench, A.F. 1997, Flow to a well of finite diameter in a homogeneous, anisotropic water table aquifer: Water Resources Research, v. 33, no. 6, p. 1397-1407.

Moench, A.F., 2003, Estimation of hectare-scale soil-moisture characteristics from aquifer-test data: Journal of Hydrology, v. 281 , p. $82-95$.

Moench, A.F., 2004, Importance of the vadose zone in analyses of unconfined aquifer tests: Ground Water, v. 42, no. 4, p. 223-233.

Moench, A.F., 2008, Analytical and numerical analyses of an unconfined aquifer test considering unsaturated zone characteristics: Water Resources Research, v. 44, W06409, doi:10.1029/2006WR005736, 17 p.

Moench, A.F., Garabedian, S.P., and LeBlanc, D.R., 2001, Estimation of hydraulic parameters from an unconfined aquifer test conducted in a glacial outwash deposit, Cape Cod, Massachusetts: U.S. Geological Survey Professional Paper 1629, 69 p.

Mualem, Yechezkel, 1976, A new model for predicting the hydraulic conductivity of unsaturated porous media: Water Resources Research, v. 12, no. 3, p. 513-522.

Narasimhan, T.N., and Zhu, Ming, 1993, Transient flow of water to a well in an unconfined aquifer-Applicability of some conceptual models: Water Resources Research, v. 29, no. 1, p. 179-191.

Neuman, S.P., 1972, Theory of flow in unconfined aquifers considering delayed response of the water table: Water Resources Research, v. 8, no. 4, p. 1031-1045.

Neuman, S.P., 1974, Effect of partial penetration on flow in unconfined aquifers considering delayed gravity response: Water Resources Research, v. 10, no. 2, p. 303-312.

Nwankwor, G.I., Cherry, J.A., and Gillham, R.W., 1984, A comparative study of specific yield determinations for a shallow sand aquifer: Ground Water, v. 22, no. 6, p. 764-772.

Nwankwor, G.I., Gillham, R.W., van der Kamp, G., and Akindunni, F.F., 1992, Unsaturated and saturated flow in response to pumping of an unconfined aquifer-Field evidence of delayed drainage: Ground Water, v. 30, no. 5, p. 690-700.

Richards, L.A., 1931, Capillary conduction of liquids in porous mediums: Physics, v. 1, p. 318-333.

Stehfest, Harald, 1970, Numerical inversion of Laplace transforms: Communications of the Association for Computing Machinery (ACM), v. 13, no. 1, p. 47-49.

Tartakovsky, G.D., and Neuman, S.P., 2007, Three-dimensional saturated-unsaturated flow with axial symmetry to a partially penetrating well in a compressible unconfined aquifer: Water Resources Research, v. 43, W01410, doi:10.1029/2006WR005153, 17 p.

Walton, W.C., 2007, Aquifer test modeling: Boca Raton, FL, CRC Press, 222 p. 
The page is intentionally left blank 


\section{Appendix 1— Data-Input Instructions for WTAO Version 2}

Description of New and Updated Program Options and Variables...............................................16

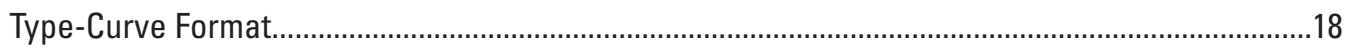

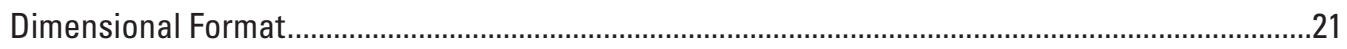

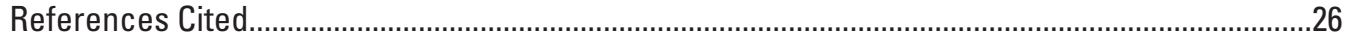




\section{Description of New and Updated Program Options and Variables}

Program options and variables that are new to WTAQ version 2 or that have been updated for version 2 of the software are described below. The user is referred to the original WTAQ documentation for a description of additional program options and variables (Barlow and Moench, 1999, p. 8-12). The data-input format for version 2 is not the same as that for version 1; therefore, input files created for version 1 will not work with version 2. Nevertheless, the changes made for version 2 are relatively minor.

Program variables are shown in upper-case text.

\section{Drainage from the unsaturated zone}

WTAQ version 2 provides three approaches for simulating drainage from the unsaturated zone to water-table aquifers. The type of drainage that is simulated is specified by variable IDRA. The first two approaches are the same as those provided in version 1 of the code: IDRA is specified to be 0 for instantaneous drainage from the unsaturated zone (that is, Neuman-type drainage) and 1 for gradual drainage from the unsaturated zone (Boulton-type drainage). If gradual drainage is specified, values of the empirical drainage constants GAMMA(I) or ALPHA(I) also must be specified, as described by Barlow and Moench (1999, p. 9). The third approach explicitly accounts for characteristics of the unsaturated zone and is based on the model of Mathias and Butler (2006). To use this approach, IDRA is set to 2, and the following four variables also must be specified: ACC, the soil-moisture retention exponent ( $a_{c}$; units of inverse length); AKK, the relative hydraulic-conductivity exponent ( $a_{k}$; units of inverse length); AMM, the initial unsaturated-zone thickness above the capillary fringe ( $m$; units of length); and AXMM, the unsaturated-zone thickness above which an assumption of an infinitely thick unsaturated-zone thickness is assumed (units of length). The value specified for AKK must be greater than or equal to that specified for ACC; otherwise, an error message will be written to the program output file and the program will terminate. As described in the "Evaluation of Revised Program" section of this report, the solution of Mathias and Butler involves less computation to evaluate if the unsaturated zone can be assumed to be of infinite thickness. To simulate an infinitely thick unsaturated zone, the user should specify a value of AMM that is greater than or equal to the value of AXMM; for a finite-thickness unsaturated zone, set AXMM greater than AMM.

\section{Numerical-Inversion Methods and Program Solution Variables}

Two methods for numerical inversion of the Laplace-transform solutions are provided with WTAQ. The user must select either the Stehfest algorithm (Stehfest, 1970) (by setting ISOLN = 1) or de Hoog algorithm (de Hoog and others, 1982) $($ ISOLN = 2). In WTAQ, the Stehfest algorithm must be used for simulation of confined aquifers. Either the Stehfest or de Hoog algorithms can be used for water-table aquifers with either instantaneous (IDRA $=0$ ) or gradual (IDRA =1) drainage from the unsaturated zone. The de Hoog algorithm must be used for water-table aquifers with drainage that is based on the Mathias and Butler (2006) model (IDRA = 2).

Each of the two numerical-inversion techniques requires specification of five program-solution variables. Those required for the Stehfest algorithm are described in Barlow and Moench (1999, p. 10). The five variables necessary for the de Hoog algorithm are RERRNR, ERROR, NTMS, NNN, and METHOD. (Variables RERRNR and NTMS also are used with the Stehfest algorithm.) Suggested values are provided for each of these variables, and the user should not have to make changes to them. Variable RERRNR is the relative error for Newton-Raphson iteration used in the finite summations of the analytical solutions for drawdown in water-table aquifers developed by Moench (1997). Smaller values of RERRNR will increase solution precision and time. A value of 1.0D-10 is suggested. If the value of RERRNR is exceeded after 100 Newton-Raphson iterations, a message is printed to the result file, and the program is stopped. Should this happen, the user can increase the value of RERRNR and re-run the simulation. Variable NTMS is a factor used to determine the number of terms in the same finite summations. Suggested values are 20 or 30 . The user should ensure that a sufficient number of terms are being used in the summations by making multiple runs in which NTMS is increased from one simulation to the next (for example, doubled) and should continue until simulation results do not vary substantially when NTMS is increased.

Variable ERROR is the relative error sought for the accuracy of the numerical inversion. A value of 1.0D-04 is recommended. Variable METHOD is an integer variable that determines the method that will be used to accelerate convergence of the summation of the Fourier series of the approximation to the inverse Laplace transform. Three options (METHOD $=1$, 2, or 3) are provided in WTAQ; the options are based on subroutine LAPADC, which was developed by John Knight (School of Mathematical Sciences, Queensland University of Technology, Brisbane, Australia) and is implemented in WTAQ. Only METHOD $=3$ has been tested with WTAQ version 2 and has been found to be satisfactory. The user can consult de Hoog and others (1982) and subroutine LAPADC for detailed discussion of the options if needed. Variable NNN is the number of terms used in the summation of the Fourier series and affects truncation and roundoff errors of the summation. NNN must 
be an even number greater than or equal to 2 . As NNN is increased, truncation error decreases, but roundoff error increases. A value of 6 is suggested, but the user can ensure that a sufficient number of terms are being used by making multiple runs in which NNN is increased from one simulation to the next and confirming that that simulation results do not vary substantially when NNN is changed. Under unusual conditions, computations of the analytical expression for drainage from the unsaturated zone (equation 42 in Mathias and Butler, 2006) may be unreliable. This can occur for small values of time or small values of dimensionless parameter $\beta$ :

$$
\beta=\left(\frac{K_{z}}{K_{r}}\right)\left(\frac{r}{b}\right)^{2},
$$

where $K_{z} / K_{r}$ is the ratio of vertical to radial hydraulic conductivity, $r$ is the radial distance of the well or observation piezometer from the center of the pumping well, and $b$ is the initial saturated thickness of the aquifer. To ensure that all of the calculations are correct, the user should check that calculated drawdowns increase smoothly with time, and that there are no oscillations in the calculated drawdowns from one time to the next.

\section{Additional Updates for Version 2}

A number of additional changes were made for version 2 to improve program operation. These changes are described here. First, although not a change from the first version of the code, to avoid confusion it should be noted that the vertical positions of the screened interval of the pumped well (variables ZPD and ZPL) and observation wells (Z1 and Z2), as well as the vertical position of the center of each piezometer (ZP), are defined with reference to the top of the aquifer or initial water table, as opposed to the height above the base of the aquifer $(z)$ as used in figures 1 and 2.

Calculations of drawdown at the pumped well usually require more computations than for distant points of observation. To avoid such computations when not needed, the variable IPUMP has been added to allow users to skip calculations of drawdown at the pumped well (IPUMP =0). Computation times also can be large for small values of $\beta$ (Moench, 1996, p. 595).

WTAQ users must now specify the name of each observation well or piezometer by use of variable OBNAME, which is a character variable that must be less than or equal to 10 characters in length.

Version 1 of WTAQ provided an option for simulation of delayed drawdown response at observation wells due to the effects of stored water within the wells but did not allow simulation of these effects at observation piezometers. This restriction has been removed for version 2. If delayed drawdown response at observation piezometers is specified (that is, variable IDPR is set to 1), the user must also specify a value of WDP (delayed-response factor) when using the type-curve format of WTAQ or values of RP (inside radius of the piezometer) and XLL (length of the screened interval of the piezometer) when using the dimensional format (see additional details about these variables in Barlow and Moench, 1999, p. 12). 


\section{Type-Curve Format}

Line-by-line instructions for creating a data-input file for the type-curve format follow. Variable names used in the input file and computer program are shown in upper-case text. As noted previously, the data-input format for version 2 of WTAQ is not the same as that for version 1; therefore, input files created for version 1 of the software will not work with version 2 .

\section{Part I: Aquifer Characteristics and General Information}

\section{Line 1: TITLE}

TITLE-Title of simulation; up to 70 characters in length. Leave this line blank if no title is specified.

Line 2: $\quad$ FORMAT

FORMAT-Analysis format. Enter TYPE CURVE.

Line 3: AQTYPE

AQTYPE—-Type of aquifer being simulated. Two options are provided:

AQTYPE $=$ CONFINED or

AQTYPE $=$ WATER TABLE

Line 4: $\quad$ BB $\quad$ XKD $\quad$ SIGMA

BB-Thickness or saturated thickness of aquifer at beginning of simulation, units of length.

XKD — Ratio of vertical to horizontal hydraulic conductivity of aquifer, dimensionless.

SIGMA - Ratio of storativity to specific yield of aquifer, dimensionless. Enter 0.0D0 if AQTYPE $=$ CONFINED.

Line 5: $\quad$ IDRA NGAMMA

IDRA - Type of drainage at water table. Enter 0 if AQTYPE $=$ CONFINED. Three options are provided:

IDRA $=0$ : Instantaneous drainage.

IDRA $=1$ : Gradual drainage

IDRA $=2$ : Drainage with unsaturated-zone characterization.

NGAMMA-Number of dimensionless drainage constants. Enter 0 if IDRA $=0$ or 2. NGAMMA must be less than or equal to 5 .

Line 6: Data input for line 6 depends on the value of IDRA.

If IDRA $=0$, enter: $\quad 1.0 \mathrm{D} 09$

If IDRA $=1$, enter: $\quad$ GAMMA(I)

GAMMA(I) - A single row of NGAMMA dimensionless drainage constants. Successive values must be separated by at least 1 space. Maximum of 5 values is allowed.

If IDRA $=2$, enter: $\quad$ ACC $\quad$ AKK $\quad$ AMM $\quad$ AXMM

ACC-Soil-moisture retention exponent, in units of inverse length.

AKK - Relative hydraulic-conductivity exponent, in units of inverse length. The value specified must be greater than or equal to that specified for ACC.

AMM - Initial unsaturated-zone thickness above the capillary fringe, in units of length.

AXMM - The unsaturated-zone thickness above the capillary fringe above which an assumption of an infinitely thick unsaturated-zone thickness is assumed, in units of length. 
Line 7: TDLAST NLC NOX

TDLAST - Largest value of dimensionless time.

NLC - Number of logarithmic cycles on the time scale for which drawdown will be calculated.

NOX - Number of equally spaced times per logarithmic cycle for which drawdown will be calculated.

Line 8: $\quad$ ISOLN

ISOLN-Numerical-inversion solution type:

ISOLN $=1$ : Solution by the Stehfest algorithm (must use this option for confined aquifers).

ISOLN = 2: Solution by the de Hoog algorithm (must use this option for IDRA = 2).

Line 9: Data input for this line depends on the value of ISOLN.

If ISOLN $=1$ (Stehfest algorithm), enter: $\quad$ RERRNR $\quad$ RERRSUM $\quad$ NMAX $\quad$ NTMS $\quad$ NS

RERRNR - Relative error for Newton-Raphson iteration and finite summations of drawdown for water-table aquifers. A value of 1.0D-10 is suggested. Enter 0.0D0 for AQTYPE = CONFINED.

RERRSUM-Relative error for finite summations of drawdown for confined aquifers. Suggested value is 1.0D-07 to 1.0D-08. Enter 0.0D0 if AQTYPE = WATER TABLE.

NMAX - Maximum number of terms permitted in the finite summations of drawdown for confined aquifers. Suggested value is 200. Enter 0 if AQTYPE = WATER TABLE.

NTMS - Factor used to determine number of terms in the finite summations for drawdown for water-table aquifers. Suggested values are 20 or 30 . Enter 0 if AQTYPE $=$ CONFINED.

NS-Number of terms used in the Stehfest algorithm. This must be an even integer, the value of which depends on computer precision. If the computer holds 16 significant figures in double precision, let $\mathrm{NS}=6$ to 12 . A value of 8 is recommended.

If ISOLN = 2 (de Hoog algorithm), enter: $\quad$ RERRNR ERROR NTMS NNN METHOD

RERRNR - Relative error for Newton-Raphson iteration and finite summations of drawdown for water-table aquifers. A value of $1.0 \mathrm{D}-10$ is suggested.

ERROR - Relative error sought for the accuracy of the numerical inversion. A value of 1.0D-04 is suggested.

NTMS - Factor used to determine number of terms in the finite summation for drawdown for water-table aquifers. Suggested values are 20 or 30 .

NNN-Number of terms used in the summation of the Fourier series of the approximation to the inverse Laplace transform. A value of 6 is suggested.

METHOD-Indicates which method will be used to accelerate convergence of the Fourier series. Options are 1, 2, or 3. Only METHOD $=3$ has been tested and was found to be satisfactory. Users can consult de Hoog and others (1982) and John Knight's subroutine LAPADC for additional details if needed. 


\section{Part II: Pumped-Well Information}

Line 10: $\quad$ IPWS IPWD IPUMP

IPWS-Type of pumped well:

IPWS $=0$ : Partially penetrating pumped well.

IPWS $=1$ : Fully penetrating pumped well.

IPWD-Type of diameter of pumped well:

IPWD $=0$ : Infinitesimal diameter (line-source theory).

$\mathrm{IPWD}=1$ : Finite diameter.

IPUMP—Option to suppress calculations of drawdown at pumped well:

IPUMP $=0$ : Drawdown is not calculated at pumped well.

IPUMP $=1$ : Drawdown is calculated at pumped well.

Line 11: $\quad$ RW $\quad$ ZPD $\quad$ ZPL $\quad$ WD $\quad$ SW

RW—Radius of pumped well screen, in units of length.

ZPD - Depth below top of aquifer or initial water table to the top of the screened interval of the pumped well, in units of length.

ZPL-Depth below top of aquifer or initial water table to the bottom of the screened interval of the pumped well, in units of length.

WD-Well-bore storage parameter, dimensionless. Enter 0.0D0 if IPWD $=0$.

SW-Well-bore skin parameter, dimensionless.

\section{Part III: Observation-Well Information}

Line 12: $\quad$ NOBWC

NOBWC - Number of observation wells or piezometers for which drawdown curves will be calculated. Must be less than or equal to 25 .

Lines 13 and 14: Repeat lines 13 and 14 for each of the NOBWC observation wells or piezometers.

Line 13: OBNAME IOWS IDPR

OBNAME—Name of observation well or piezometer; up to 10 characters in length.

IOWS-Type of observation well or piezometer:

IOWS $=0$ : Partially penetrating observation well.

IOWS $=1$ : Fully penetrating observation well.

IOWS $=2$ : Observation piezometer.

IDPR - Options for delayed response of observation well.

IDPR $=0$ : No delayed response.

IDPR $=1$ : Delayed response. 
$\begin{array}{llllll}\text { Line 14: } & \mathrm{R} & \mathrm{Z} 1 & \mathrm{Z} 2 & \mathrm{ZP} & \text { WDP }\end{array}$

$\mathrm{R}$-Radial distance from axis of pumped well to observation well or piezometer, in units of length.

Z1-Depth below top of aquifer or initial water table to the top of screened interval of observation well, in units of length. Use for IOWS $=0$ or 1 . Enter 0.0D0 if IOWS $=2$.

Z2 - Depth below top of aquifer or initial water table to the bottom of screened interval of observation well, in units of length.

Use for IOWS $=0$ or 1 . Enter 0.0D0 if IOWS $=2$.

$\mathrm{ZP}-$ Depth below top of aquifer or initial water table to center of piezometer, in units of length. Use for IOWS $=2$. Enter 0.0D0 if IOWS $=0$ or 1.

WDP-Delayed response factor, dimensionless. Enter 0.0D0 if IDPR $=0$.

\section{Dimensional Format}

Line-by-line instructions for creating a data-input file for the dimensional format follow. Variable names used in the input file and computer program are shown in upper-case text. As noted previously, the data-input format for version 2 of WTAQ is not the same as that for version 1; therefore, input files created for version 1 of the software will not work with version 2.

\section{Part I: Aquifer Characteristics and General Information}

Line 1: TITLE

TITLE-Title of simulation; up to 70 characters in length. Leave this line blank if no title is specified.

Line 2: $\quad$ FORMAT

FORMAT—Analysis format. Enter DIMENSIONAL.

Line 3: AQTYPE

AQTYPE—Type of aquifer being simulated. Two options are provided:

AQTYPE $=$ CONFINED or

AQTYPE $=$ WATER TABLE

Line 4: $\quad$ BB $\quad$ HKR $\quad$ HKZ $\quad$ SS $\quad$ SY

BB - Thickness or saturated thickness of aquifer at beginning of simulation, in units of length.

HKR - Horizontal hydraulic conductivity of aquifer, in units of length per time.

HKZ - Vertical hydraulic conductivity of aquifer, in units of length per time.

SS-Specific storage of aquifer, in units of inverse length.

SY - Specific yield of aquifer, dimensionless. Enter 0.0D0 if AQTYPE = CONFINED.

Line 5: $\quad$ IDRA NALPHA

IDRA - Type of drainage at water table. Enter 0 if AQTYPE $=$ CONFINED. Three options are provided:

IDRA $=0$ : Instantaneous drainage.

IDRA $=1$ : Gradual drainage.

IDRA $=2$ : Drainage with unsaturated-zone characterization.

NALPHA-Number of drainage constants. Enter 0 if IDRA $=0$ or 2. NALPHA must be less than or equal to 5 . 


\section{WTAQ Version 2-A Computer Program for Analysis of Aquifer Tests in Confined and Water-Table Aquifers}

Line 6: Data input for line 6 depends on the value of IDRA.

If IDRA $=0$, enter: $\quad 1.0 \mathrm{D} 09$

If IDRA $=1$, enter: $\quad$ ALPHA(I)

ALPHA(I) - A single row of NALPHA drainage constants, in units of inverse time. Successive values must be separated by at least 1 space. Maximum of 5 values is allowed.

If IDRA $=2$, enter: $\quad$ ACC $\quad$ AKK $\quad$ AMM AXMM

ACC - Soil-moisture retention exponent, in units of inverse length.

AKK-Relative hydraulic-conductivity exponent, in units of inverse length. The value specified must be greater than or equal to that specified for ACC.

AMM - Initial unsaturated-zone thickness above the capillary fringe, in units of length.

AXMM - The unsaturated-zone thickness above the capillary fringe above which an assumption of an infinitely thick unsaturated-zone thickness is assumed, in units of length.

Line 7: $\quad$ ITS IMEAS

ITS-Time specification:

ITS $=0:$ Log-cycle time steps (use to generate theoretical curves).

ITS $=1:$ User-specified times.

IMEAS-Specification of measured drawdown data. Enter 0 if ITS $=0$. Options for ITS $=1$ :

IMEAS $=0$ : Measured drawdown data not specified for each time.

IMEAS $=1$ : Measured drawdown data specified for each time.

Line 8: $\quad$ TLAST NLC NOX

TLAST - Largest value of time. Enter 0.0D0 if ITS $=1$.

NLC - Number of logarithmic cycles on the time scale for which drawdown will be calculated. Enter 0 if ITS $=1$.

NOX - Number of equally spaced times per logarithmic cycle for which drawdown will be calculated. Enter 0 if ITS $=1$.

Line 9: $\quad$ ISOLN

ISOLN-Numerical-inversion solution type:

ISOLN $=1$ : Solution by the Stehfest algorithm (must use this option for confined aquifers).

ISOLN = 2: Solution by the de Hoog algorithm (must use this option for IDRA = 2). 
Line 10: Data input for line 10 depends on the value of ISOLN.

$\underline{\text { If ISOLN }=1 \text { (Stehfest algorithm), enter: }}$ RERRNR $\quad$ RERRSUM $\quad$ NMAX $\quad$ NTMS NS

RERRNR - Relative error for Newton-Raphson iteration and finite summations of drawdown for water-table aquifers. A value of 1.0D-10 is suggested. Enter 0.0D0 for AQTYPE $=$ CONFINED.

RERRSUM-Relative error for finite summations of drawdown for confined aquifers. Suggested value is 1.0D-07 to 1.0D-08. Enter 0.0D0 if AQTYPE = WATER TABLE.

NMAX-Maximum number of terms permitted in the finite summations of drawdown for confined aquifers. Suggested value is 200. Enter 0 if AQTYPE $=$ WATER TABLE.

NTMS - Factor used to determine number of terms in the finite summations for drawdown for water-table aquifers. Suggested values are 20 or 30 . Enter 0 if AQTYPE $=$ CONFINED.

NS-Number of terms used in the Stehfest algorithm. This must be an even integer, the value of which depends upon computer precision. If the computer holds 16 significant figures in double precision, let NS $=6$ to 12 . A value of 8 is recommended.

If ISOLN $=2$ (de Hoog algorithm), enter: $\quad$ RERRNR ERROR NTMS NNN METHOD

RERRNR-Relative error for Newton-Raphson iteration and finite summations of drawdown for water-table aquifers. A value of $1.0 \mathrm{D}-10$ is suggested.

ERROR—-Relative error sought for the accuracy of the numerical inversion. A value of 1.0D-04 is suggested.

NTMS - Factor used to determine number of terms in the finite summation for drawdown for water-table aquifers. Suggested values are 20 or 30 .

NNN - Number of terms used in the summation of the Fourier series of the approximation to the inverse Laplace transform. A value of 6 is suggested.

METHOD - Indicates which method will be used to accelerate convergence of the Fourier series. Options are 1, 2, or 3. Only METHOD $=3$ has been tested and was found to be satisfactory. Users can consult de Hoog and others (1982) and John Knight's subroutine LAPADC for additional details if needed.

\section{Part II: Pumped-Well Information}

Line 11: IPWS IPWD IPUMP

IPWS-Type of pumped well:

IPWS $=0$ : Partially penetrating pumped well.

IPWS $=1$ : Fully penetrating pumped well.

IPWD - Type of diameter of pumped well:

IPWD $=0$ : Infinitesimal diameter (line-source theory).

IPWD $=1$ : Finite diameter.

IPUMP - Option to suppress calculations of drawdown at pumped well:

IPUMP $=0$ : Drawdown is not calculated at pumped well.

IPUMP $=1$ : Drawdown is calculated at pumped well. 


\section{WTAQ Version 2-A Computer Program for Analysis of Aquifer Tests in Confined and Water-Table Aquifers}

$\begin{array}{llllll}\text { Line 12: } & \text { QQ } & \text { RW } & \text { RC } & \text { ZPD } & \text { ZPL }\end{array}$

QQ-Pumping rate of well, in units of cubic length per time.

RW-Radius of pumped well screen, in units of length.

RC-Inside radius of pumped well in the interval where water levels are changing during pumping, in units of length.

Enter 0.0D0 if IPWD $=0$.

ZPD - Depth below top of aquifer or initial water table to the top of the screened interval of the pumped well, in units of length.

ZPL-Depth below top of aquifer or initial water table to the bottom of the screened interval of the pumped well, in units of length.

SW-Well-bore skin parameter, dimensionless.

Lines 13 and 14: Information on user-specified times for which drawdowns will be calculated for the pumped well. Skip to line 15 if ITS $=0$.

Line 13: NTSPW IRUN

NTSPW-Number of user-specified times for which drawdown at the pumped well will be calculated. If NTSPW $=0$, no drawdowns are calculated for the pumped well.

IRUN-Option to suppress drawdown calculations for the pumped well. Allows user to specify time-drawdown data (Line 14), but those data are ignored during the simulation. Options are:

IRUN $=0$ : Drawdowns not calculated

IRUN $=1$ : Drawdowns calculated.

Line 14: Time and measured drawdown data for pumped well. Repeat this line of input data NTSPW times (if NTSPW $=0$, skip to line 15): TIMEPW(I) $\quad$ XMEASPW(I)

TIMEPW(I)-Time I.

XMEASPW(I)—Measured drawdown at pumped well for time I, in units of length. Leave blank if IMEAS $=0$.

\section{Part III: Observation-Well Information}

\section{Line 15: $\quad$ NOBWC}

NOBWC-Number of observation wells or piezometers for which drawdown curves will be calculated. Must be less than or equal to 25 .

Lines 16 through 19: Repeat lines 16 through 19 for each of the NOBWC observation wells or piezometers.

Line 16: OBNAME IOWS IDPR

OBNAME-Name of observation well or piezometer; up to 10 characters in length.

IOWS-Type of observation well or piezometer:

IOWS $=0$ : Partially penetrating observation well.

IOWS $=1$ : Fully penetrating observation well.

IOWS $=2$ : Observation piezometer.

IDPR - Options for delayed response of observation well.

IDPR $=0$ : No delayed response.

$\mathrm{IDPR}=1$ : Delayed response. 
$\begin{array}{lllllll}\text { Line 17: } & \mathrm{R} & \mathrm{Z} 1 & \mathrm{Z} 2 & \text { ZP } & \text { RP } & \text { XLL }\end{array}$

$\mathrm{R}$-Radial distance from axis of pumped well to observation well or piezometer, in units of length.

Z1-Depth below top of aquifer or initial water table to the top of screened interval of observation well, in units of length. Use for IOWS $=0$ or 1 . Enter 0.0D0 if IOWS $=2$.

Z2- Depth below top of aquifer or initial water table to the bottom of screened interval of observation well, in units of length. Use for IOWS $=0$ or 1 . Enter $0.0 \mathrm{D} 0$ if IOWS $=2$.

$\mathrm{ZP}$-Depth below top of aquifer or initial water table to center of piezometer, in units of length. Use for IOWS $=2$. Enter $0.0 \mathrm{D} 0$ if IOWS $=0$ or 1 .

$\mathrm{RP}$ - Inside radius of the observation well (or piezometer) standpipe in the interval over which water levels are changing during pumping, in units of length. Enter 0.0D0 if IDPR $=0$.

XLL — Length of screened interval of observation well or piezometer, in units of length. Enter 0.0D0 if IDPR $=0$.

Lines 18 and 19: Information on user-specified times for which drawdowns will be calculated for the observation well or piezometer. Skip these lines if ITS $=0$.

Line 18: NTSOB IRUN

NTSOB-Number of user-specified times for which drawdown at the observation well or piezometer will be calculated. If $\mathrm{NTSOB}=0$, no drawdowns are calculated for the observation well or piezometer.

IRUN-Option to suppress drawdown calculations for the observation well or piezometer. Allows user to specify timedrawdown data (Line 19), but those data are ignored during the simulation. Options are:

IRUN $=0$ : Drawdowns not calculated.

IRUN $=1$ : Drawdowns calculated.

Line 19: Time and measured drawdown data for observation well or piezometer. Repeat this line of input data NTSOB times (if $\mathrm{NTSOB}=0$, skip to next observation point): $\quad$ TIMEOB(I) $\quad$ XMEASOB(I)

TIMEOB(I)—Time I.

XMEASOB(I)-Measured drawdown at observation well or piezometer for time I, in units of length. Leave blank if IMEAS $=0$. 


\section{References Cited}

Barlow, P.M., and Moench, A.F., 1999, WTAQ_-A computer program for calculating drawdowns and estimating hydraulic properties for confined and water-table aquifers: U.S. Geological Survey Water-Resources Investigations Report 99-4225, $74 \mathrm{p}$.

de Hoog, F.R., Knight, J.H., and Stokes, A.N., 1982, An improved method for numerical inversion of Laplace transforms: SIAM Journal of Scientific Computing, v, 3, p. 357-366.

Mathias, S.A., and Butler, A.P., 2006, Linearized Richards' equation approach to pumping test analysis in compressible aquifers: Water Resources Research, v. 42, W06408, doi:10.1029/2005WR004680, 10 p.

Moench, A.F., 1996, Flow to a well in a water-table aquifer: An improved Laplace transform solution: Ground Water, v. 34, no. 4, p. 593-596.

Moench, A.F. 1997, Flow to a well of finite diameter in a homogeneous, anisotropic water table aquifer: Water Resources Research, v. 33, no. 6, p. 1397-1407.

Stehfest, Harald, 1970, Numerical inversion of Laplace transforms: Communications of the Association for Computing Machinery (ACM), v. 13, no. 1, p. 47-49. 
Figures 9 and 10 
Figure 9. Data-input file for sample problem.

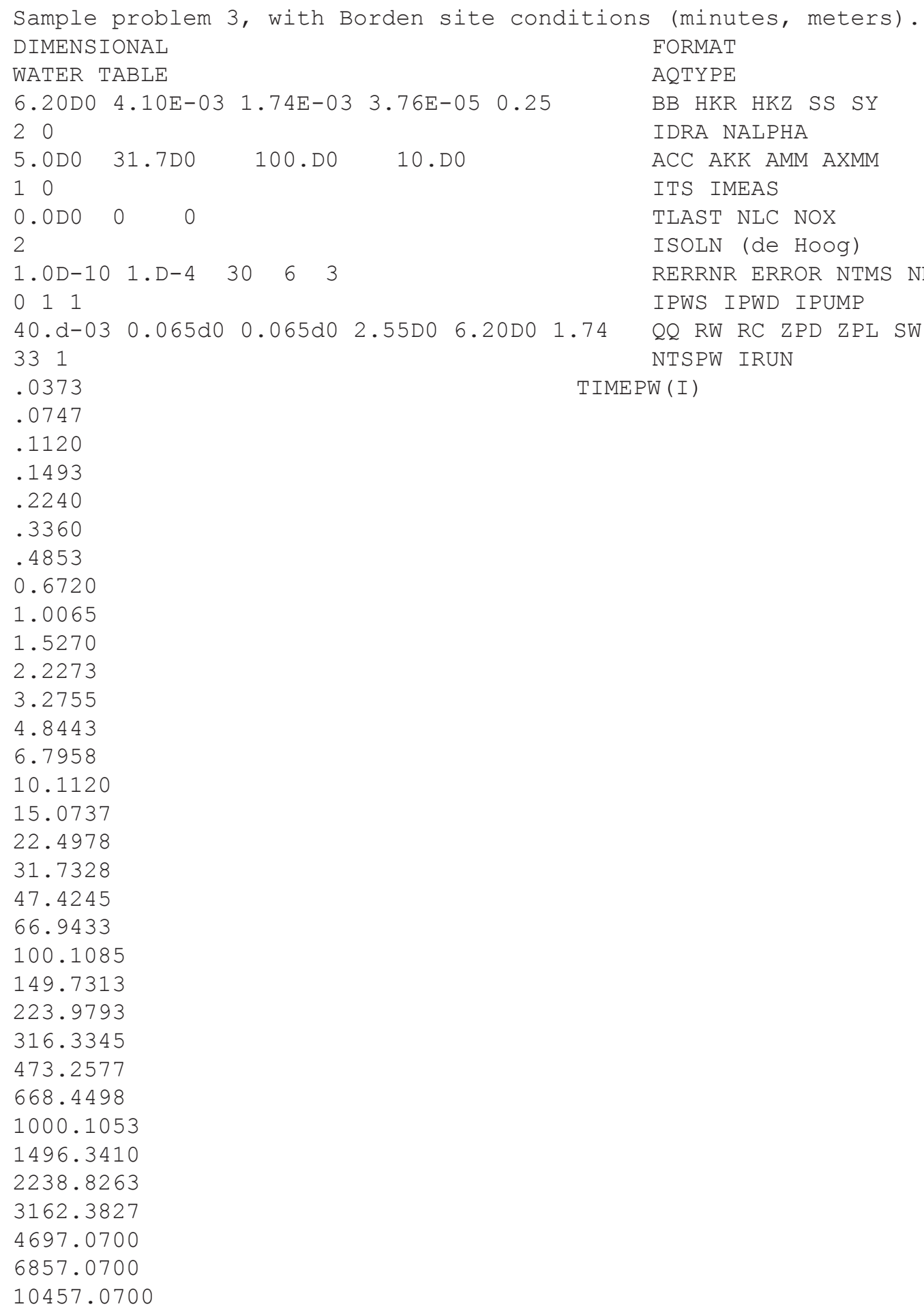


7

WD1A 21

1.510 .0

281

.3360

.4853

0.6720

1.0065

1. 5270

2. 2273

3. 2755

4.8443

6.7958

10.1120

15.0737

22.4978

31.7328

47.4245

66.9433

100.1085

149.7313

223.9793

316.3345

473.2577

668.4498

1000.1053

1496.3410

2238.8263

3162.3827

4697.0700

6857.0700

10457.0700

WD2A 21

5.070 .0

291

.2240

.3360

.4853

0.6720

1.0065

1.5270

2. 2273

3.2755

4.8443

6.7958

10.1120

15.0737

22.4978

31.7328

47.4245

66.9433

100.1085

149.7313

223.9793

316.3345

473.2577

668.4498 $\begin{array}{llll}0.0 & 0.94 & 0.025 & 0.35\end{array}$

NOBWC

OBNAME IOWS IDPR

WD1A: R Z1 Z2 ZP RP XLL

NTSOB IRUN

TIMEOB ( I )
0.0
0.89
0.025
0.35
WD2A
NTSOB IRUN
TIMEOB ( I ) 
1000.1053

1496.3410

2238.8263

3162.3827

4697.0700

6857.0700

10457.0700

WD4A 21

15.050 .0

271

.4875

0.6750

1. 0252

1.4930

2.1933

3.2415

4.8103

6.7618

10.0780

15.0397

22.4638

31.6988

47.3905

66.9093

100.0745

149.6973

223.9453

316.3005

473.2237

668.4158

1000.0713

1496.3070

2238.7923

3162.3487

4697.0360

6857.0360

10457.0360

$\mathrm{P} 1721$

$\begin{array}{lll}5.15 & 0.0\end{array}$

331

.0375

.0750

.1125

.1500

.2250

.3375

.4875

0.6750

1.0252

1.4930

2.1933

3. 2415

4.8103

6.7618

10.0780

15.0397

22.4638 $\begin{array}{llll}0.0 & 0.84 & 0.025 & 0.35\end{array}$

WD4A

NTSOB IRUN

TIMEOB ( I ) $\begin{array}{llllll}0.0 & 2.69 & 0.025 & 0.35 & \text { P17 } & \\ & & & \text { NTSOB IRUN }\end{array}$

TIMEOB ( I ) 


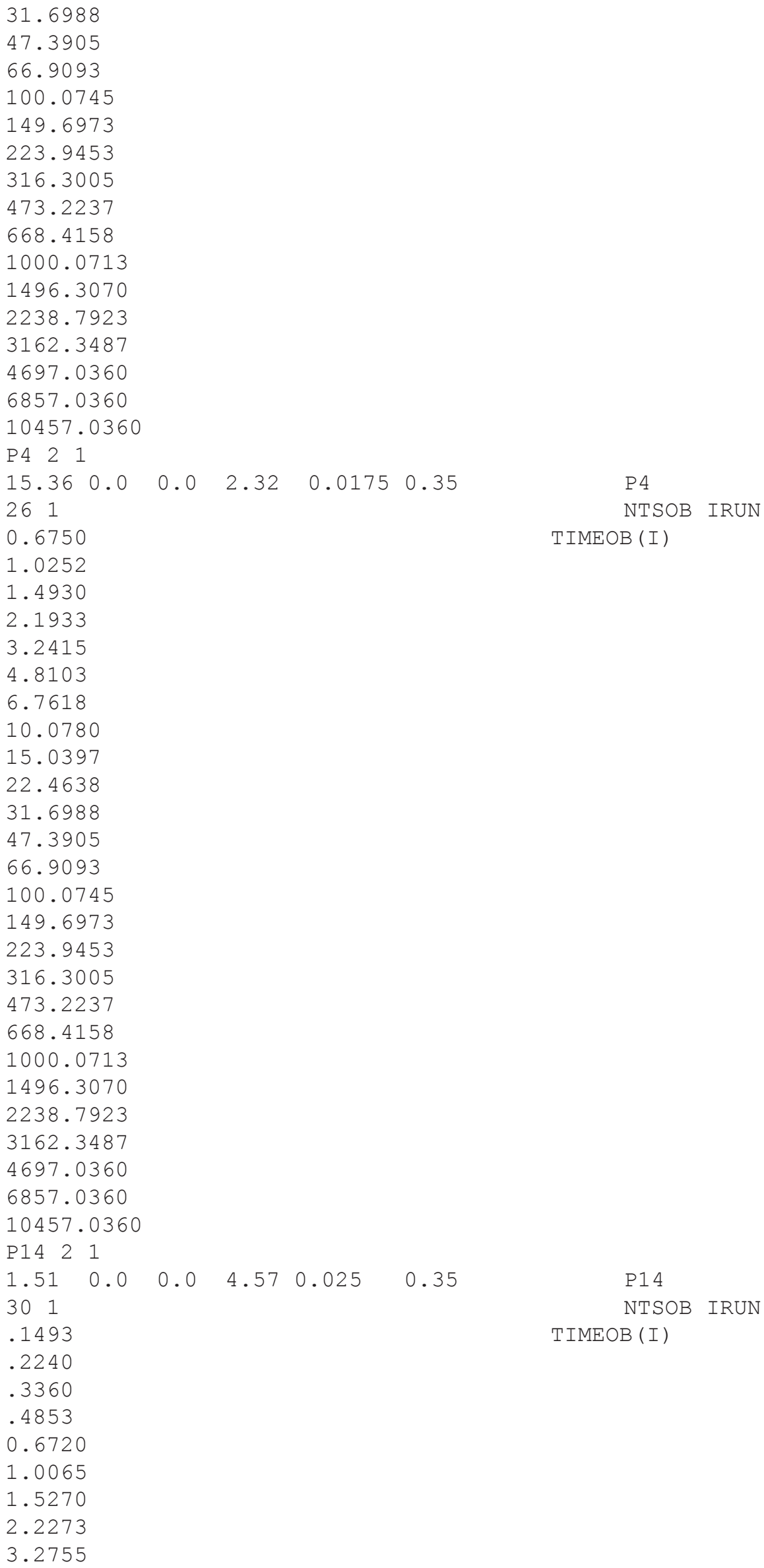




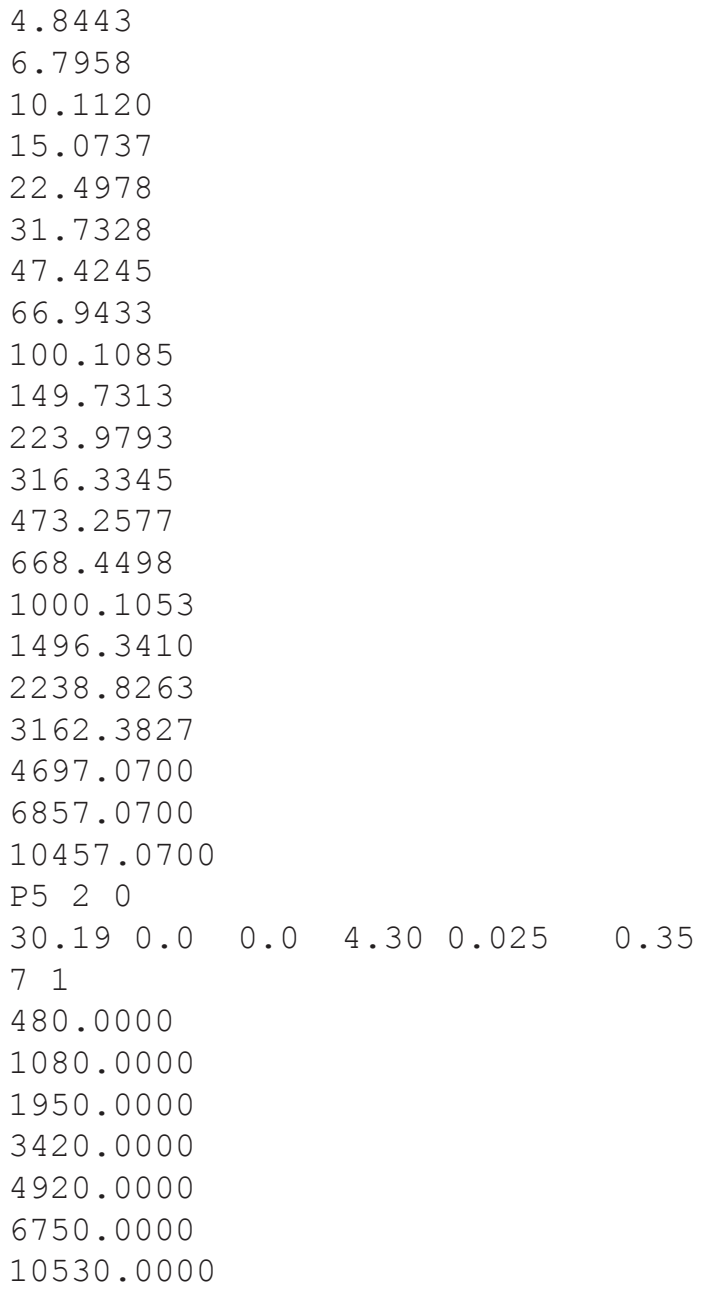


Figure 10. Output-results file for sample problem.

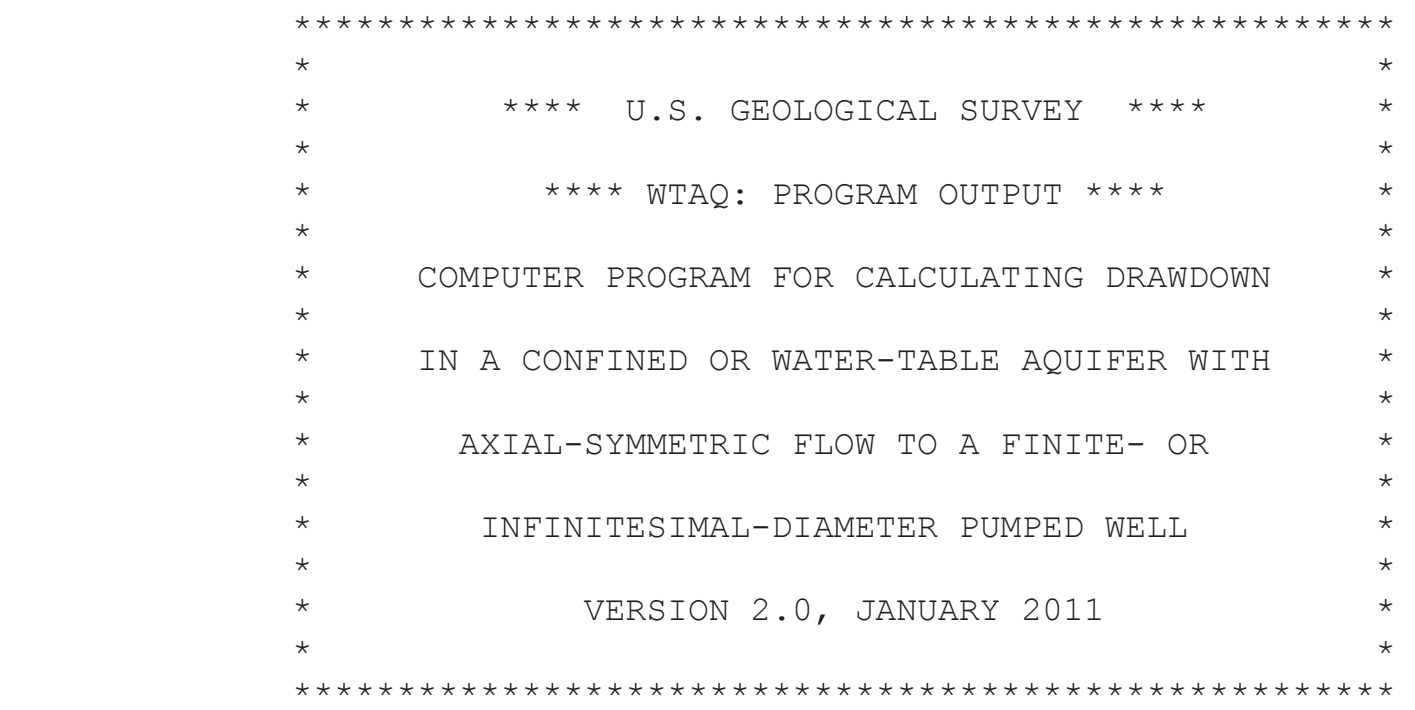

Sample problem 3, with Borden site conditions (minutes, meters).

DIMENSIONAL FORMAT WATER-TABLE AQUIFER

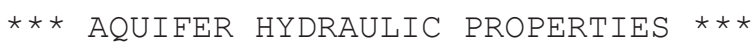

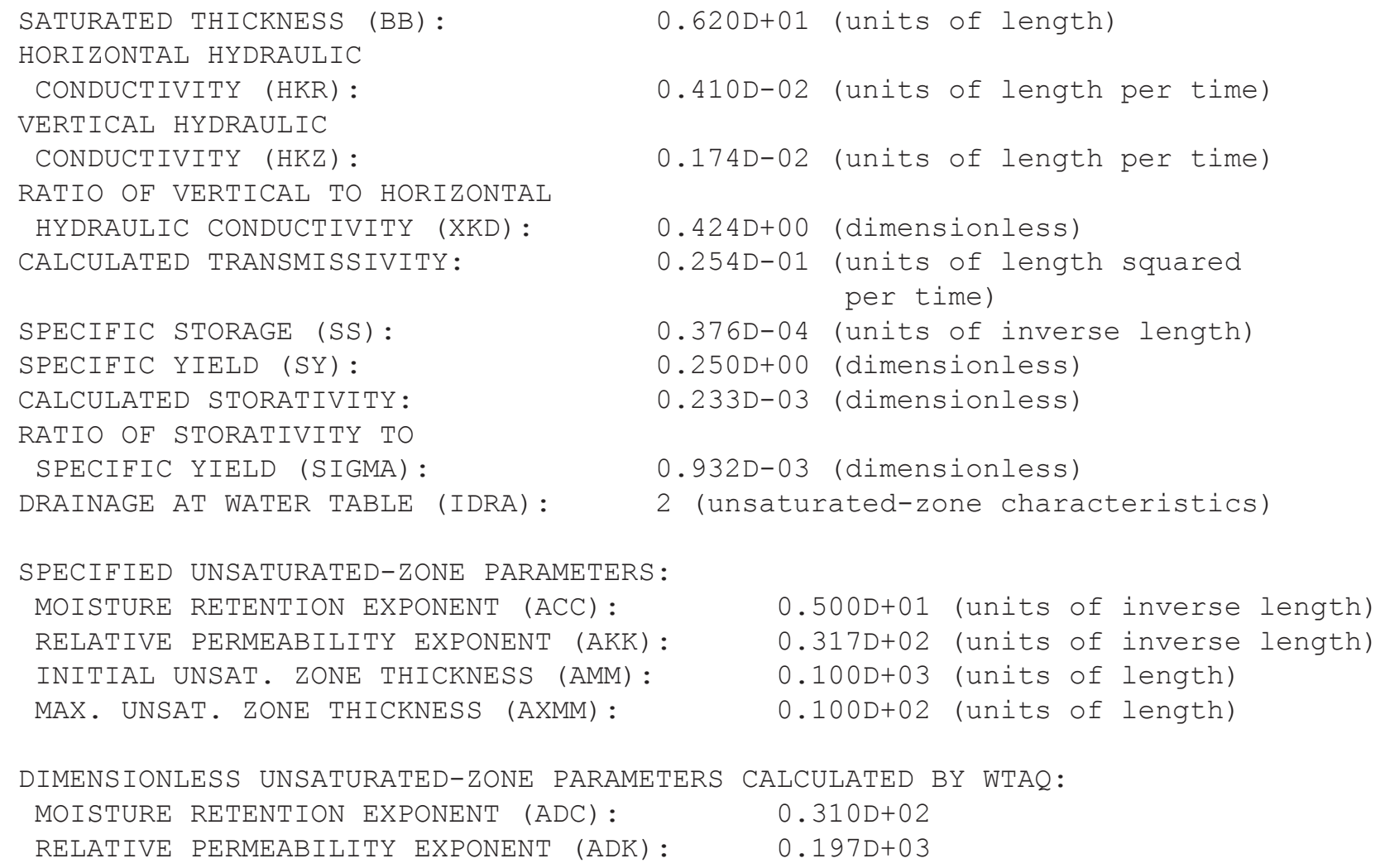


34 WTAQ Version 2-A Computer Program for Analysis of Aquifer Tests in Confined and Water-Table Aquifers
INITIAL UNSAT. ZONE THICKNESS (ADM) :
$0.161 \mathrm{D}+02$
MAX. UNSAT. ZONE THICKNESS (XMAXDM) :
$0.161 \mathrm{D}+01$

INITIAL SATURATED THICKNESS OF UNSATURATED ZONE IS GREATER THAN THE MAXIMUM UNSATURATED-ZONE THICKNESS SPECIFIED: SATURATED-ZONE THICKNESS ASSUMED INFI-

NITE.

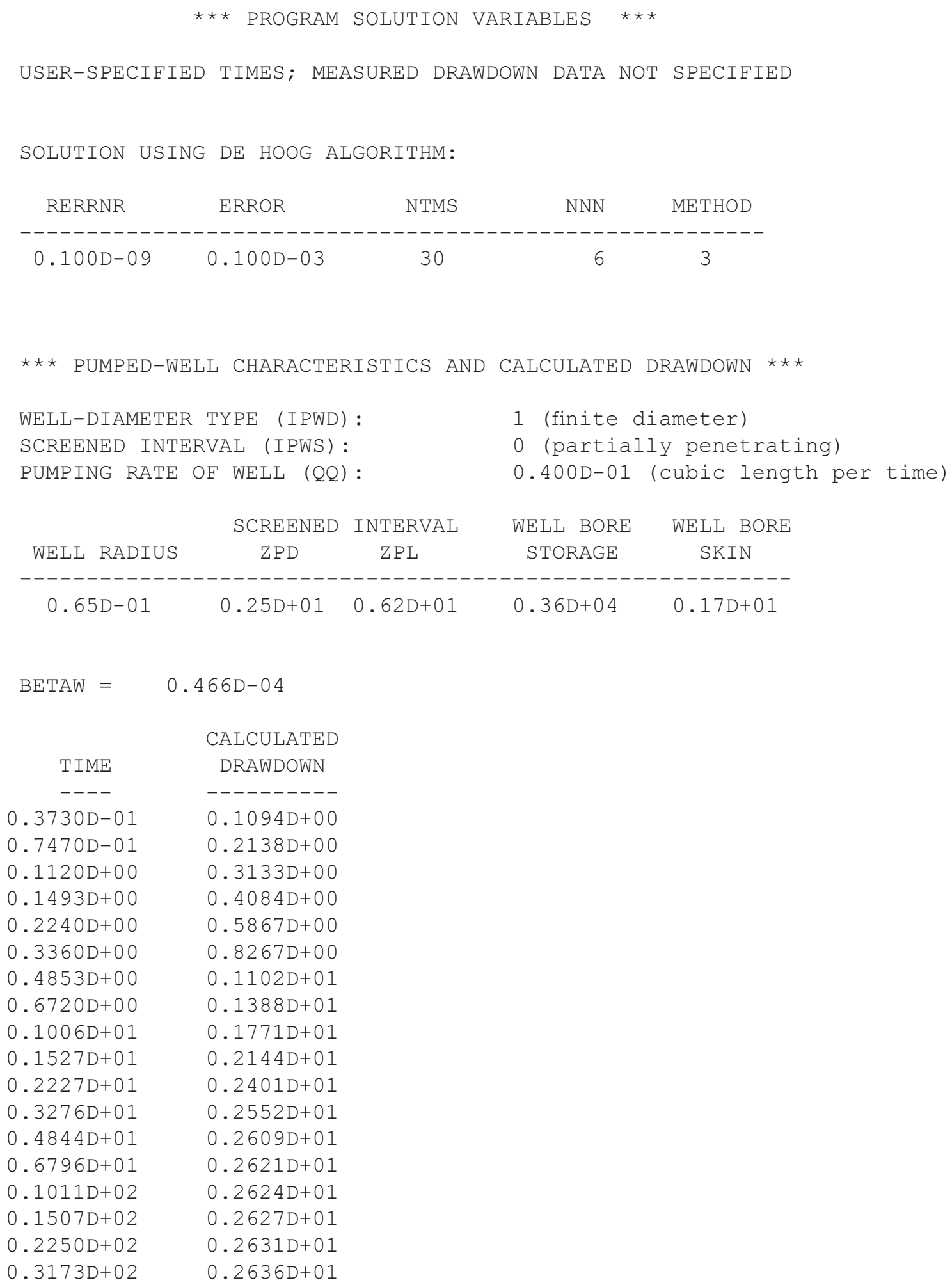




$\begin{array}{ll}0.4742 \mathrm{D}+02 & 0.2643 \mathrm{D}+01 \\ 0.6694 \mathrm{D}+02 & 0.2650 \mathrm{D}+01 \\ 0.1001 \mathrm{D}+03 & 0.2662 \mathrm{D}+01 \\ 0.1497 \mathrm{D}+03 & 0.2677 \mathrm{D}+01 \\ 0.2240 \mathrm{D}+03 & 0.2696 \mathrm{D}+01 \\ 0.3163 \mathrm{D}+03 & 0.2716 \mathrm{D}+01 \\ 0.4733 \mathrm{D}+03 & 0.2743 \mathrm{D}+01 \\ 0.6684 \mathrm{D}+03 & 0.2771 \mathrm{D}+01 \\ 0.1000 \mathrm{D}+04 & 0.2806 \mathrm{D}+01 \\ 0.1496 \mathrm{D}+04 & 0.2845 \mathrm{D}+01 \\ 0.2239 \mathrm{D}+04 & 0.2887 \mathrm{D}+01 \\ 0.3162 \mathrm{D}+04 & 0.2925 \mathrm{D}+01 \\ 0.4697 \mathrm{D}+04 & 0.2969 \mathrm{D}+01 \\ 0.6857 \mathrm{D}+04 & 0.3013 \mathrm{D}+01 \\ 0.1046 \mathrm{D}+05 & 0.3062 \mathrm{D}+01\end{array}$

*** OBSERVATION-WELL CHARACTERISTICS AND CALCULATED DRAWDOWN ***

OBSERVATION WELL OR PIEZOMETER: WD1A

OBSERVATION PIEZOMETER

\begin{tabular}{|c|c|c|}
\hline DISTANCE FROM & & \\
\hline CENTER OF & & DELAYED RESPONSE \\
\hline PUMPED WELL & ZP & FACTOR \\
\hline
\end{tabular}
$0.151 \mathrm{D}+01$
$0.940 \mathrm{D}+00$
$0.173 D+05$

DRAWDOWN CALCULATED FOR BETA $=0.252 \mathrm{D}-01$

\begin{tabular}{|c|c|}
\hline TIME & $\begin{array}{l}\text { CALCULATED } \\
\text { DRAWDOWN }\end{array}$ \\
\hline---- & ----------- \\
\hline $0.3360 D+00$ & $0.4394 \mathrm{D}-02$ \\
\hline $0.4853 D+00$ & $0.9478 D-02$ \\
\hline $0.6720 \mathrm{D}+00$ & $0.1747 D-01$ \\
\hline $0.1006 \mathrm{D}+01$ & $0.3360 \mathrm{D}-01$ \\
\hline $0.1527 D+01$ & $0.5725 \mathrm{D}-01$ \\
\hline $0.2227 D+01$ & $0.8052 \mathrm{D}-01$ \\
\hline $0.3276 \mathrm{D}+01$ & $0.9923 \mathrm{D}-01$ \\
\hline $0.4844 D+01$ & $0.1097 D+00$ \\
\hline $0.6796 \mathrm{D}+01$ & $0.1143 \mathrm{D}+00$ \\
\hline $0.1011 D+02$ & $0.1189 \mathrm{D}+00$ \\
\hline $0.1507 D+02$ & $0.1246 \mathrm{D}+0 \mathrm{C}$ \\
\hline $0.2250 D+02$ & $0.1321 \mathrm{D}+00$ \\
\hline $0.3173 D+02$ & $0.1403 \mathrm{D}+0 \mathrm{C}$ \\
\hline $0.4742 \mathrm{D}+02$ & $0.1527 D+0 C$ \\
\hline $0.6694 \mathrm{D}+02$ & $0.1662 \mathrm{D}+0$ \\
\hline $0.1001 D+03$ & $0.1858 \mathrm{D}+0$ \\
\hline $0.1497 D+03$ & $0.2104 \mathrm{D}+0$ \\
\hline
\end{tabular}




$\begin{array}{ll}0.2240 \mathrm{D}+03 & 0.2400 \mathrm{D}+00 \\ 0.3163 \mathrm{D}+03 & 0.2694 \mathrm{D}+00 \\ 0.4733 \mathrm{D}+03 & 0.3079 \mathrm{D}+00 \\ 0.6684 \mathrm{D}+03 & 0.3439 \mathrm{D}+00 \\ 0.1000 \mathrm{D}+04 & 0.3883 \mathrm{D}+00 \\ 0.1496 \mathrm{D}+04 & 0.4345 \mathrm{D}+00 \\ 0.2239 \mathrm{D}+04 & 0.4817 \mathrm{D}+00 \\ 0.3162 \mathrm{D}+04 & 0.5226 \mathrm{D}+00 \\ 0.4697 \mathrm{D}+04 & 0.5698 \mathrm{D}+00 \\ 0.6857 \mathrm{D}+04 & 0.6150 \mathrm{D}+00 \\ 0.1046 \mathrm{D}+05 & 0.6657 \mathrm{D}+00\end{array}$

OBSERVATION WELL OR PIEZOMETER: WD2A

\begin{tabular}{ccc} 
OBSERVATION & PIEZOMETER \\
DISTANCE FROM & & \\
CENTER OF & & DELAYED RESPONSE \\
PUMPED WELL & ZP & FACTOR \\
$-0.507 \mathrm{D}+01$ & $0.890 \mathrm{D}+00$ & $0.173 \mathrm{D}+05$ \\
\multicolumn{5}{c}{} \\
DRAWDOWN CALCULATED FOR BETA
\end{tabular}



$0.4697 \mathrm{D}+04$
$0.4575 \mathrm{D}+00$
$0.6857 \mathrm{D}+04$
$0.5024 \mathrm{D}+00$
$0.1046 \mathrm{D}+05$
$0.5527 \mathrm{D}+00$

OBSERVATION WELL OR PIEZOMETER: WD4A

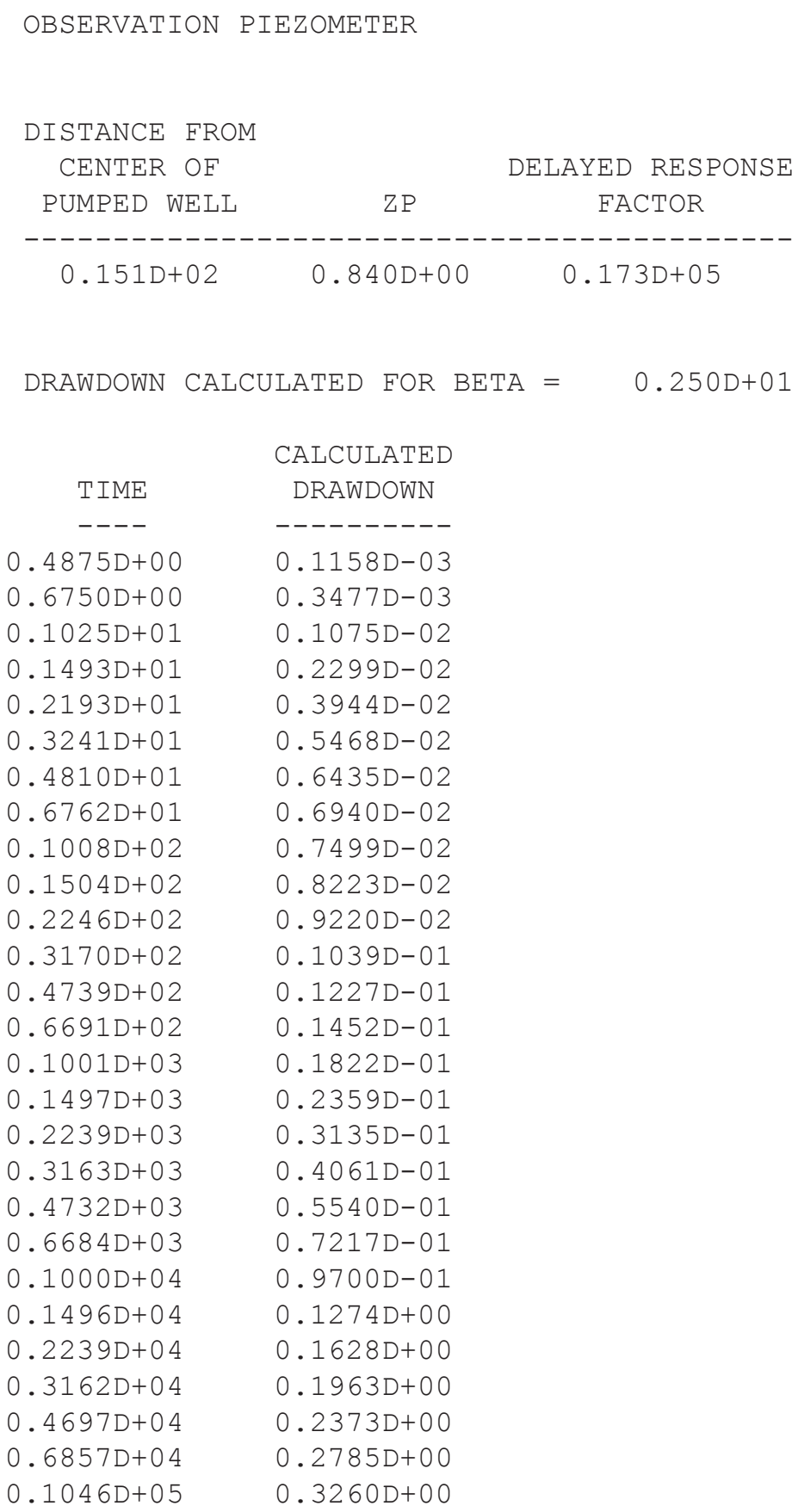


OBSERVATION WELL OR PIEZOMETER: P17

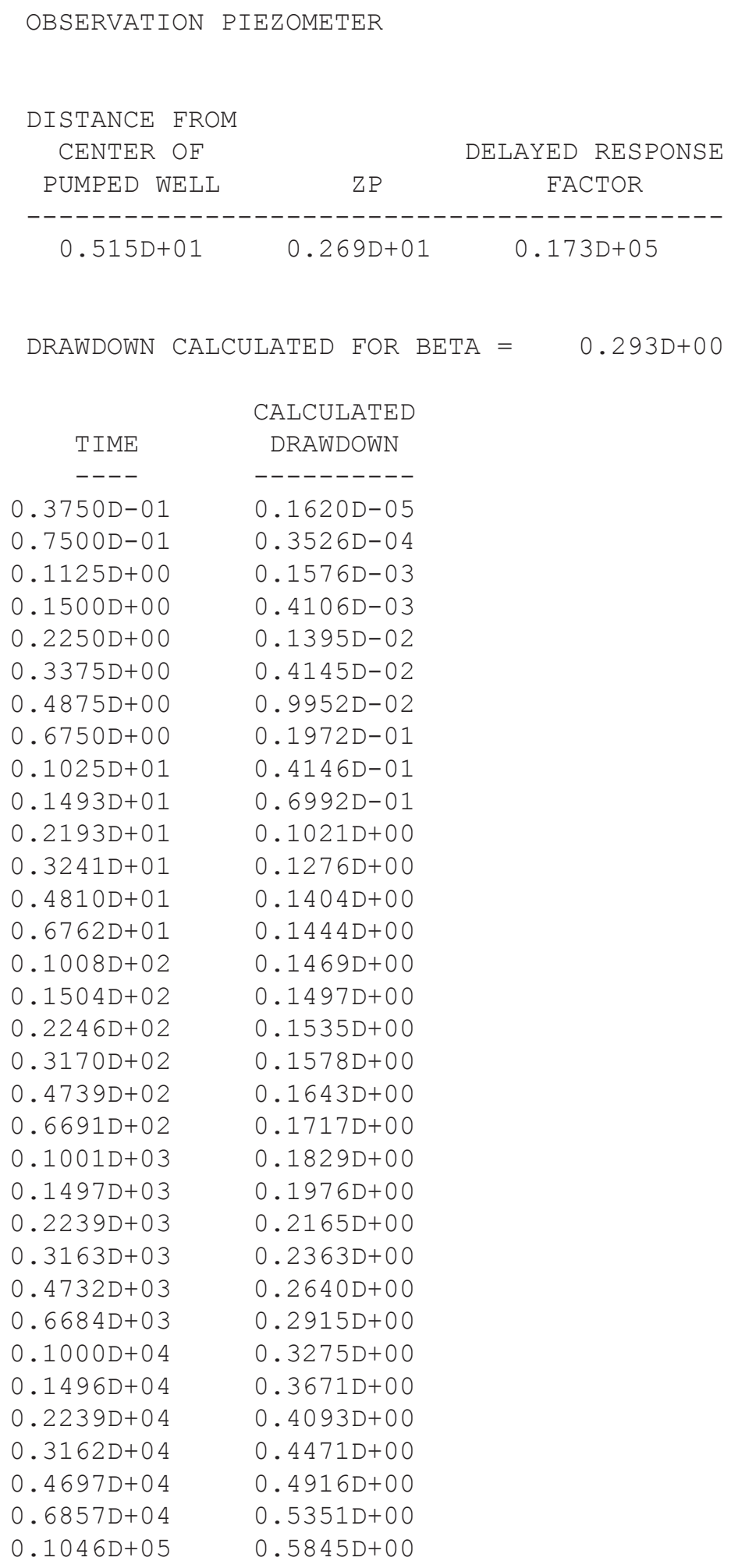

------------------------------------------


OBSERVATION WELL OR PIEZOMETER: P4

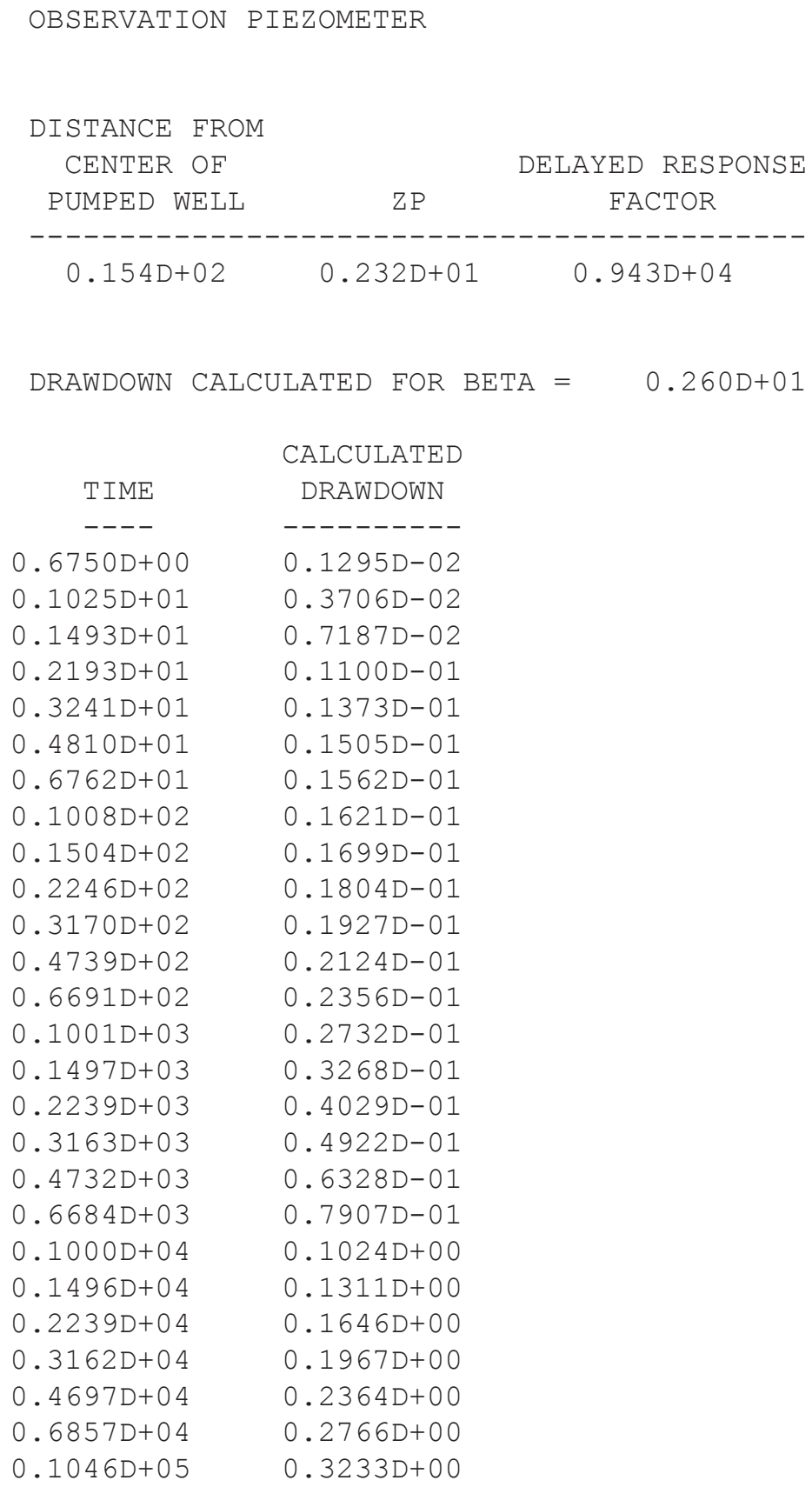

OBSERVATION WELL OR PIEZOMETER: P14

OBSERVATION PIEZOMETER

DISTANCE FROM

CENTER OF DELAYED RESPONSE

PUMPED WELL ZP FACTOR



$0.151 D+01$
$0.457 D+01$
$0.173 D+05$

DRAWDOWN CALCUI

TIME

\section{CALCULATED}

--DRAWDOWN

$0.1493 D+00$

$0.6028 \mathrm{D}-02$

$0.2240 D+00$

$0.1464 \mathrm{D}-01$

$0.3360 \mathrm{D}+00$

$0.3357 \mathrm{D}-01$

$0.4853 \mathrm{D}+00$

$0.6728 \mathrm{D}-01$

$0.6720 \mathrm{D}+00$

$0.1178 D+00$

$0.1006 \mathrm{D}+01$

$0.2156 \mathrm{D}+00$

$0.1527 \mathrm{D}+01$

$0.3534 \mathrm{D}+00$

$0.2227 \mathrm{D}+01$

$0.4835 \mathrm{D}+00$

$0.3276 \mathrm{D}+01$

$0.5816 \mathrm{D}+00$

$0.4844 \mathrm{D}+01$

$0.6271 \mathrm{D}+00$

$0.6796 \mathrm{D}+01$

$0.6381 \mathrm{D}+00$

$0.1011 \mathrm{D}+02$

$0.6415 \mathrm{D}+00$

$0.1507 \mathrm{D}+02$

$0.6443 \mathrm{D}+00$

$0.2250 \mathrm{D}+02$

$0.6480 \mathrm{D}+00$

$0.3173 \mathrm{D}+02$

$0.6522 \mathrm{D}+00$

$0.4742 \mathrm{D}+02$

$0.6585 \mathrm{D}+00$

$0.6694 \mathrm{D}+02$

$0.6656 \mathrm{D}+00$

$0.1001 \mathrm{D}+03$

$0.6765 \mathrm{D}+00$

$0.1497 \mathrm{D}+03$

$0.6906 \mathrm{D}+00$

$0.2240 D+03$

$0.7087 \mathrm{D}+00$

$0.3163 D+03$

$0.7277 \mathrm{D}+00$

$0.4733 \mathrm{D}+03$

$0.7544 \mathrm{D}+00$

$0.6684 \mathrm{D}+03$

$0.7809 \mathrm{D}+00$

$0.1000 \mathrm{D}+04$

$0.8158 \mathrm{D}+00$

$0.1496 \mathrm{D}+04$

$0.8543 \mathrm{D}+00$

$0.2239 \mathrm{D}+04$

$0.8957 \mathrm{D}+00$

$0.3162 \mathrm{D}+04$

$0.9330 \mathrm{D}+00$

$0.4697 \mathrm{D}+04$

$0.9770 \mathrm{D}+00$

$0.6857 \mathrm{D}+04$

$0.1020 D+01$

$0.1046 \mathrm{D}+05$

$0.1069 D+01$ 


\section{OBSERVATION WELL OR PIEZOMETER: P5}

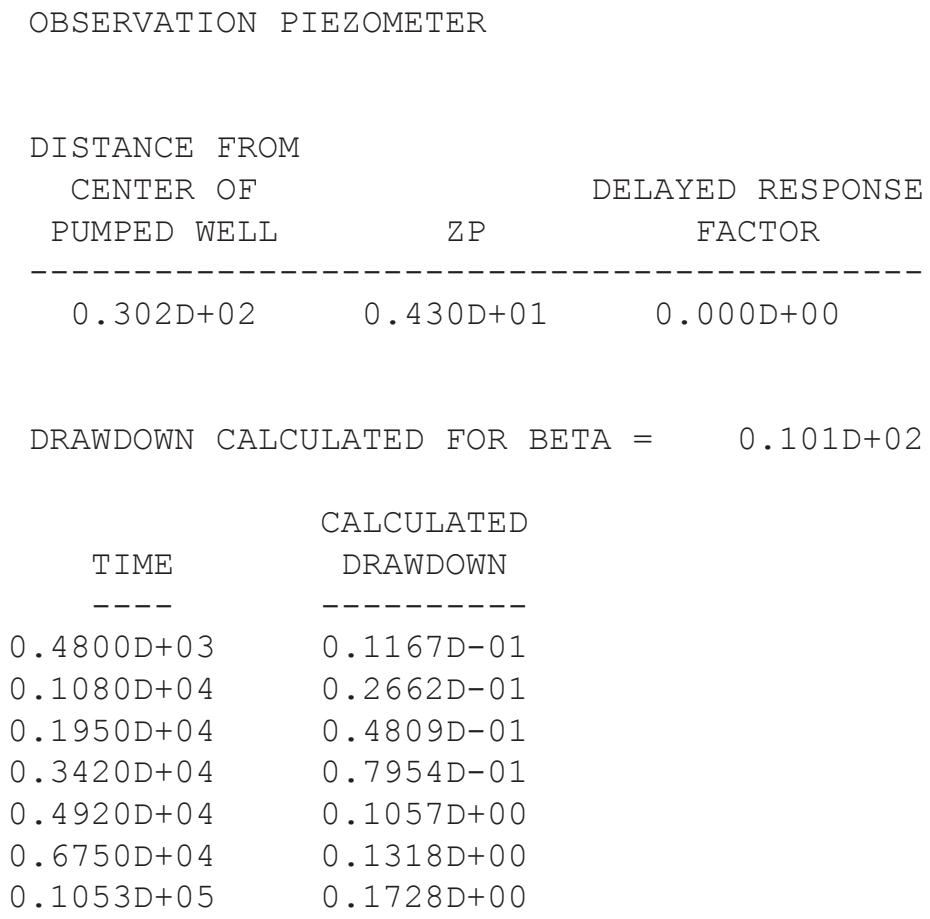



Prepared by the Pembroke and West Trenton Publishing Service Centers.

For more information concerning this report, contact:

Office of Groundwater

U.S. Geological Survey

411 National Center

Reston, VA 20192

(703) 648-5001 


\section{这}

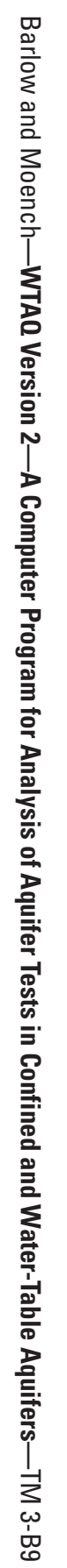

